\title{
Negative-pressure pneumatic separator: a new solution for hard- coal beneficiation
}

\author{
Kamil Stańczyk ${ }^{1}$ (1) · Andrzej Bajerski ${ }^{1} \cdot$ Marian J. Lączny $^{1}$
}

Received: 20 December 2019/Revised: 27 April 2020/Accepted: 2 July 2020/Published online: 23 July 2020

(C) The Author(s) 2020

\begin{abstract}
Hard coal is an important source of energy worldwide. Owing to the imperfections of excavation technology, most run-of-mine coals must be processed before they can be utilised as fuel. In this study, tests on the dry separation process were performed with numerous different raw hard coal and coal waste material samples, using a newly designed and constructed negative-pressure pneumatic separator (NPPS). The experiments revealed the effects of the feed-material properties and material processing conditions. These experiments were preceded by additional tests for evaluating the influence of each device operating parameter on the process, to determine the optimal method of supplying the feed material. The calorific value of the processed materials was improved by $5 \%-40 \%$, while a minimal output yield of products $(60 \%-70 \%)$ was maintained. The trials indicated that in coal material processing, the developed NPPS can be used for not only raw coal enrichment but also coal recovery from materials stored at coal-waste dumps. The main advantages of the device are its mobility, low material processing cost, and lack of water consumption during operation.
\end{abstract}

Graphic abstract

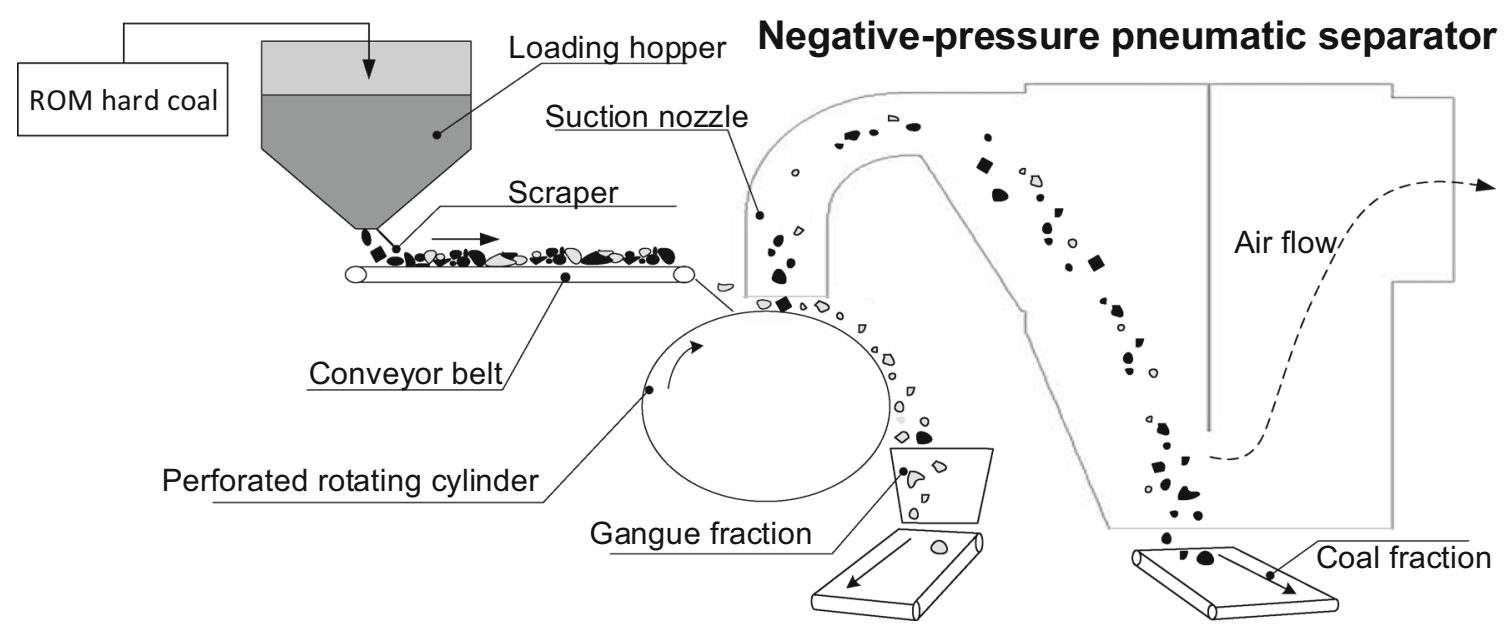

Kamil Stańczyk

kastanczyk@gig.eu

1 Central Mining Institute, Plac Gwarków 1, 40-166 Katowice,

Poland 
Keywords Dry coal beneficiation · Coal enrichment - Coal waste processing · Aerodynamic separation · Deshaling . Negative-pressure system

\section{Introduction}

Coal plays an important role in satisfying global energy demands, because it is widely available, safe, reliable, and inexpensive (World Energy Council 2013). Despite the rapid development of renewable energy technologies, fossil fuels remain dominant source of energy, with coal being the second-largest energy source worldwide (US Department of Energy 2016). According to forecasts, coal consumption will remain at the current level at least until 2040 (US Department of Energy 2017). Coal is a crucial resource for the security of energy supply in developed countries, and it is a key enabler for economic growth in developing countries (World Energy Council 2016). However, the use of coal raises ecological concerns. To mitigate the environmental impact, it is necessary to develop new technologies. Importantly, the ecological impact of coal use is determined by not only the combustion technology but also the preceding operations, such as excavation, coal processing, and transport.

Owing to the imperfections of excavation technology, most run-of-mine (ROM) coals must be processed before they can be utilised as fuel. Ash-forming impurities must be removed through the coal beneficiation process, which can increase the carbon concentration, reduce the environmental impact of emissions, and reduce the transportation weight and waste-disposal expenses (Lockhart 1984; Van Houwelingen and De Jong 2004; Dwari and Hanumantha 2007). Recent research indicated that coal processing makes a significant implicit contribution to the lifecycle energy efficiency of coal (Wang et al. 2019). Various enrichment techniques have been developed over the past century, and among them, wet methods are most commonly used, owing to their high precision (Infomine Research Group 2015). Coal-processing technology is being continuously developed with the implementation of new solutions and improvements to existing ones (Galvin et al. 1999; Nguyentranlam and Galvin 2001; Galvin et al. 2002; Honaker et al. 2007; Sarkar et al. 2008; Das et al. 2009; Honaker et al. 2010; Hacifazlioglu 2012; Vasumathi et al. 2016). Currently, the largest coal recipients, i.e. power plants, can ecologically use even low-quality coal owing to their well-developed combustion technology. Thus, it is not always justified to process coal via wet methods that are known not only for their precision but also high costs and technological complexity; wet processing of coal requires a large amount of water, and the waste generated ties up a significant amount of water and land.
Moreover, the formed slurry ponds may pose serious operational problems (Sahu et al. 2009). In practice, coal with a lower calorific value (LCV) of approximately $21,000-23,000 \mathrm{~kJ} / \mathrm{kg}$ is considered to be suitable for power generation. To achieve such an LCV, it is often sufficient to improve the raw coal calorific value by approximately $1500-3000 \mathrm{~kJ} / \mathrm{kg}$. Thus, the implementation of less precise but more ecological and economical methods might prove reasonable.

The pneumatic separation process is an alternative to the wet methods of enrichment. It has regained attention and has been redeveloped in the twenty-first century (Honaker et al. 2008; Iskhakhov et al. 2008; Patil and Parekh 2011; Xuliang et al. 2012; Baic et al. 2014; Zhao et al. 2014; Chalavadi and Das 2015; Całus Moszko et al. 2016; Davaasuren et al. 2016; Gupta 2016; Mijał and Tora 2018; Fu et al. 2019; Yang et al. 2019). Dry separation of coal, which is commonly referred to as deshaling, involves the separation of grains in the rising or pulsing air stream, depending on the differences in the physical properties between coal and gangue minerals, such as the grain density, size, and shape and the surface roughness. Deshaling has lower processing costs than wet methods owing to its simplicity. Additionally, it can be implemented in regions where an extreme climate or a lack of water prevents the use of wet methods. However, the quality of the products obtained via aerodynamic separation is inferior to that of the products acquired via wet methods. Moreover, the deshaling process often requires additional preliminary preparation of feed material for efficient operation.

This paper presents the results of tests performed on a negative-pressure pneumatic separator (NPPS) - a device for the pneumatic separation of grain materials-designed at Central Mining Institute under an international project. The main objective was to assess the capability of the device for the dry enrichment of coal materials. Additionally, owing to the worldwide growing problem of coalwaste storage and utilisation (Battioui et al. 2013; Fan et al. 2014; Ciesielczuk 2015), the possibility of coal recovery from gangue materials stored at coal-waste dumps was examined. The tests were performed using several different Polish raw coals and coal waste materials. 


\section{Materials and methods}

\subsection{Experimental procedure}

The main objective of the experiments was to determine the process efficiency with the use of selected ROM coal materials. The results indicate whether the pneumatic separation of these materials is a suitable processing method to achieve the required product properties.

The research included the following:

(1) determination of the optimum feeding conditions, i.e. the layer thickness of the feed material, linear velocity of the conveyor belt and rotary cylinder, and position of the suction nozzle relative to the rotary cylinder;

(2) evaluation of the effects of the physical properties of the grains (size, density, and shape) on the suction efficiency;

(3) evaluation of the effects of the fan speed on the calorific value and ash content in the products of dry separation for selected ROM hard coals; and

(4) determination of the relationship between the fan speed and the parameters of the products obtained through processing of selected waste materials.

\subsection{Experimental setup}

The sorting method is based on the separation of the feedmaterial grains using a negative pressure, which is generated by a nozzle located above the layer of enriched material; this pressure sets the particles in motion. The separation occurs owing to differences in the size, density, and shape of the grains. Implementing the perforated working surface in the form of a rotating cylinder allows for an overpressure to be generated under the layer of grains of the enriched materials. This overpressure together with the curvature of the cylindrical working surface improves the efficiency of the sorting process through the initiation of grain vibrations and their mutual displacement, as well as the drying of grains, reducing the possibility of grain sticking. The experiments were conducted using the equipment for pneumatic separation, which is presented in Figs. 1 and 2.

The installation used for the dry separation process comprised a loading hopper (1) as a reservoir to prepare the material for the sorting process. The material is discharged from the hopper and transported by a conveyor belt (2) onto a rotary cylinder made of a perforated cylindrical surface (3). Inside the rotary cylinder is a directional nozzle and an auxiliary blow fan (4). The outlet of the directional nozzle is directed upwards, perpendicular to the surface of the rotating cylinder. The suction nozzle (5) is above the rotary cylinder. The sucked material grains are transported to a particle separator (6), where they are separated from the air stream and led into the reservoir of the sucked fraction (9), while the non-sucked fraction slides from the cylinder directly into the reservoir (10) intended for nonsucked grain collection. The air flow intensity is regulated by a main suction fan (7). Before it leaves the system, the air stream is purified in the dust collector to remove the remaining solid particles (8).

The construction of the NPPS allows for adjusting the following work parameters:

(1) the speed of the conveyor belt (inverter control in the range of $0-50 \mathrm{~Hz}$ );

(2) the speed of the rotary cylinder (inverter control in the range of $0-50 \mathrm{~Hz}$ );

(3) the rotational speed of the fan (inverter control in the range of $20-50 \mathrm{~Hz}$ );

(4) the position of the suction nozzle above the surface of the rotating cylinder (manual control); and

(5) the position of the scraper, i.e. its height above the conveyor belt (manual control).

In practice, the speed of the rotary cylinder is programmed to depend on the speed of the conveyor belt, for maintaining a constant linear speed throughout the feeding system.

A slow-motion video of the suction zone during the operation of the device is presented in Online Resource 2 $(\text { Appendix B })^{1}$.

\subsection{Methodology}

\subsubsection{Initial optimisation of process}

To investigate the relationship between the quality and quantity of the products obtained under the specific main suction fan settings, supplementary tests were performed to define the optimal way of delivering the feed material. It has been assumed that increasing the processing capacity may reduce the suction efficiency.

The feed rate can be adjusted by changing the position of the scraper and/or by changing the speed of the conveyor belt. The position of the scraper affects the layer thickness of the material leaving the loading hopper; together with conveyor belt speed setting, it determines the amount of material being discharged from the hopper per unit time. Tests were performed to examine the effect of the mass flow rate delivered to the suction zone on the suction efficiency.

\footnotetext{
${ }^{1}$ Data accessible at Mendeley data. https://doi.org/10.17632/ 57f28ph87t.1.
} 


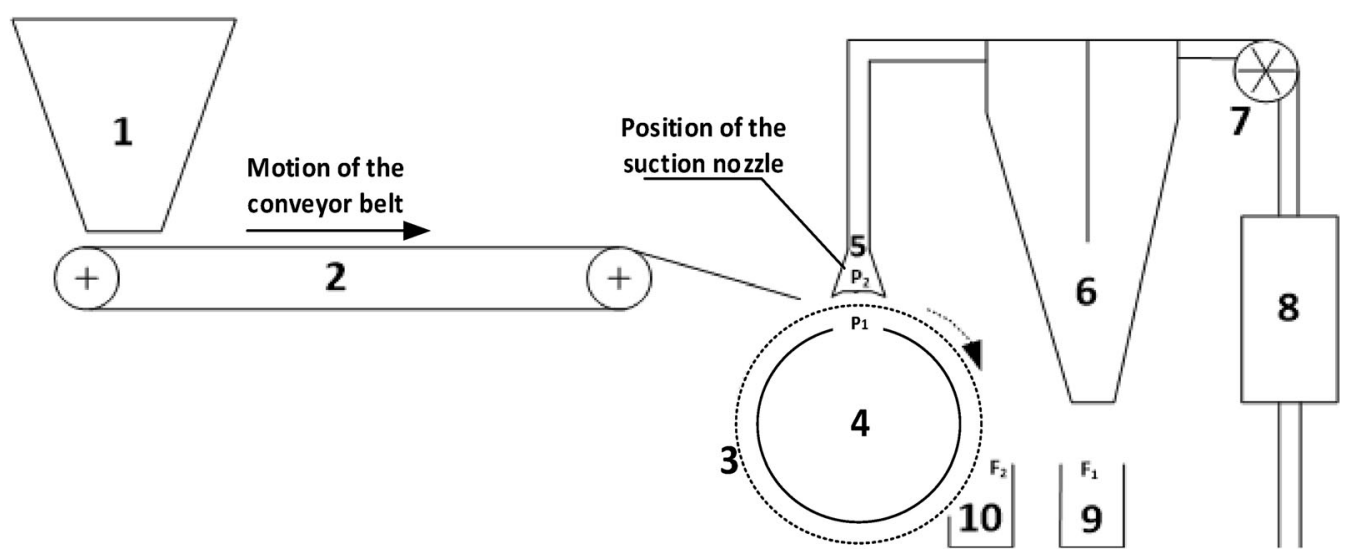

Fig. 1 Outline of installation for the dry separation process: 1-loading hopper with mounted scraper; 2-conveyor belt; 3 -perforated rotating cylinder; 4—auxiliary fan and directional nozzle; 5—-suction nozzle; 6-separator; 7—main suction fan; 8—dust collector; 9 and 10-reservoirs for grains

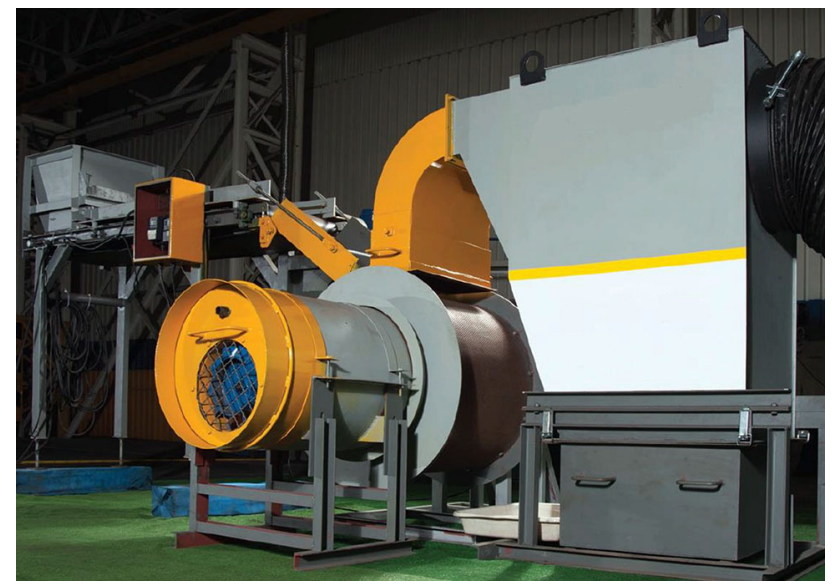

Fig. 2 Installation for the dry separation process

Proper positioning of the suction nozzle above the surface of the perforated rotary cylinder is crucial for efficient operation. To examine the influence of the suction nozzle position on the process, a two-dimensional coordinate system was defined, with the origin set at the top of the rotary cylinder. The vertical position of the nozzle ( $y$ coordinate) was set as low as possible for a given type of feed material. To ensure the smooth transfer of grains in the suction area, this height was set to 1.5 multiplied by the largest grain diameter in the feed being processed (e.g. $y=75 \mathrm{~mm}$ for processing material in the $20-50 \mathrm{~mm}$ grainsize class). Thus, the focus of the experiments was to assess how changing the nozzle position in the horizontal direction influences the suction efficiency. Figure 3 presents a diagram of the feeding system, with the nozzle set to the " 0 " position.

To determine optimal feeding conditions, the following samples of feed materials were prepared.
(1) Research on the optimal thickness of the feed material layer

Processed coal (obtained via wet enrichment methods), grain-size classes of 5-25 and $30-50 \mathrm{~mm}$

(2) Research on the optimal speeds (linear velocities) of the conveyor belt and rotary cylinder

raw coal, grain-size class of $0-20 \mathrm{~mm}$

(3) Research on the optimal position of the suction nozzle:

a) processed coal with ash content of approximately $4 \mathrm{wt} \%$, grain-size class of $30-50 \mathrm{~mm}$

b) coal waste originating from wet coal enrichment process, grain-size class of $10-30 \mathrm{~mm}$

\subsubsection{Effects of grain properties on suction efficiency}

The effects of the feed-material properties, such as the grain size, shape, and density and the moisture content, on the suction efficiency were investigated. Additionally, the effect of the moisture content on the amount of particles sucked into the main-fan channel was assessed. This amount represents the dust-collector load during the device operation.

To examine the effect of the feed moisture content on the amount of material sucked by the suction nozzle and into the main-fan channel, raw coal samples in the grainsize classes of $0-20$ and $5-20 \mathrm{~mm}$ were prepared with three different moisture-content conditions (air-dried, asreceived, wetted through addition of approximately $5 \mathrm{wt} \%$ of water). 


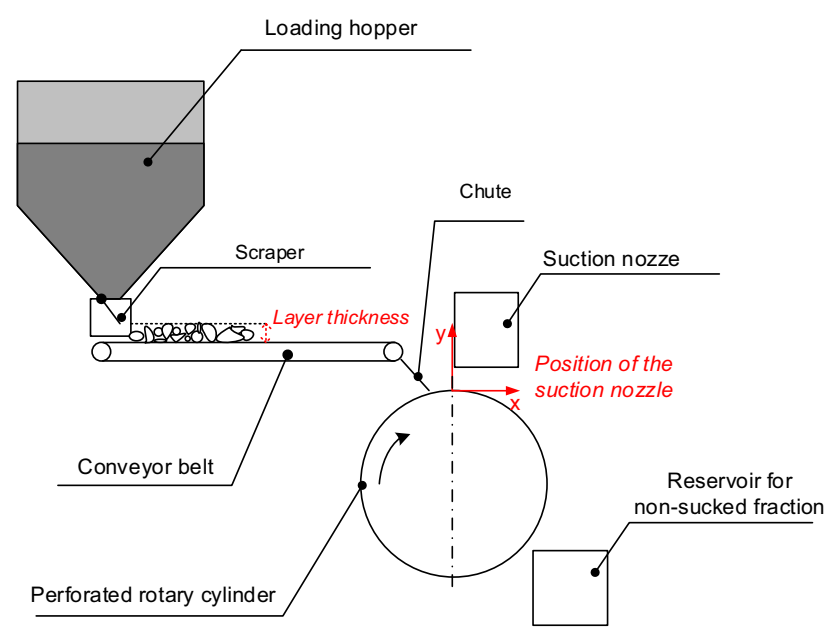

Fig. 3 Diagram of the feeding system

To determine the relationships between the grain properties (size, shape, density) and the suction efficiency, three sets of tests (for two materials each) were performed.

The juxtaposed materials were prepared to maximise the impact of one selected property.

The physical phenomena occurring in the suction zone were analysed in detail. The relationship between the airflow velocity and the main fan operating frequency was investigated through additional measurements. This allowed us to connect the experimental results with the theory.

\subsubsection{Main experiments}

The objective of the main experiments was to obtain separation curves describing the relationship between the product quality and the output yields under certain negative-pressure conditions caused by the main fan. The optimal operating conditions for a given feed material should be determined empirically, by performing a series of trials and drawing the separation curve.

To determine the relationship between the main-fan speed and the properties of the products, as well as their output yields, a series of trials was performed.

Before the feeding, the raw materials were divided into three grain-size classes: 0-50 $\mathrm{mm}$ (as-received), 0-20 mm, and $20-50 \mathrm{~mm}$. Additionally, three of them (No. 1, 2 and 6) were prepared as ecological fuel for domestic boilers $(6-20 \mathrm{~mm})$. The tests were performed with different fan speeds and vertical nozzle positions (adjusted according to the maximum grain size). The products of the process were then examined in an accredited laboratory at Central Mining Institute. The quality of the products was determined according to their ash content and LCV.
The research methodology, which was based on the sorter construction and was suitable for analysing the separation process, consisted of the following.

(1) preparation of the feed material in predefined grainsize classes, i.e. a mining product (raw hard coal) or waste material (coal waste from selected dumps)

dry separation tests using the prepared feed material samples and sampling of the products

analysis of the results, i.e. determining the product quality and suitability as fuel (LCV, ash content) evaluation of the process effectiveness and its suitability for coal enrichment

The particle separator was equipped with a pressure sensor, which allowed for monitoring of the pressure generated by the main fan during the process. This monitoring was useful for detecting malfunctions of the device during its operation and provided essential data for the development of models of the process.

\subsubsection{Measurement uncertainty}

Determining the measurement uncertainty of the experimental data is of utmost importance for assessing the reliability of the results. Complementary tests were performed to define the uncertainty of the output yield and ash content of the products obtained through the beneficiation process.

The uncertainty was determined as the combined standard uncertainty (i.e. combination of type A and type B evaluation), with type A evaluated through the t-distribution owing to the small number of samples (sample size $n \leq 30$ ) (JCGM 2008; Internet source: Wikipedia; Klonecki 1999).

$u(x)=\sqrt{s_{\bar{x}}^{2}+\frac{\left(\Delta_{d} x\right)^{2}}{3}+\frac{\left(\Delta_{e} x\right)^{2}}{3}}$

where, $s_{\bar{x}}^{2}$ is standard deviation of the mean value (t-distribution); $\Delta_{d} x$ is calibration uncertainty; $\Delta_{e} x$ is investigator uncertainty.

\subsection{Materials}

Two types of feed materials were used in the experiments: raw ROM coals and coal waste from selected waste dumps. The raw coals were acquired from eight different excavations located in seven different Polish hard coal mines. All the coals and coal waste were received as material in the grain-size class of $0-50 \mathrm{~mm}$. The coal waste was acquired from two different Silesian waste dumps, as samples in the grain-size class of $0-20 \mathrm{~mm}$. Each feed material had to be pre-treated before being subjected to the separation 
Table 1 Density distribution of material No. 1 (grain-size class: 0-20 mm)

\begin{tabular}{|c|c|c|c|c|}
\hline \multirow[t]{2}{*}{ Grain density $\delta\left(\mathrm{g} / \mathrm{cm}^{3}\right)$} & \multicolumn{2}{|l|}{ Yield } & \multicolumn{2}{|l|}{ Ash content, A } \\
\hline & Fraction $\gamma_{n}(\%)$ & Cumulative $\gamma_{n}^{k}(\%)$ & Fraction $\lambda_{n}(\%)$ & Cumulative $\vartheta_{n}(\%)$ \\
\hline$<1.4$ & 65.2 & 65.2 & 3.7 & 3.7 \\
\hline $1.4-1.5$ & 2.3 & 67.5 & 19.6 & 4.3 \\
\hline $1.5-1.6$ & 2.3 & 69.8 & 27.8 & 5.0 \\
\hline $1.6-1.7$ & 1.8 & 71.6 & 37.5 & 5.9 \\
\hline $1.7-1.8$ & 1.3 & 72.9 & 44.4 & 6.6 \\
\hline $1.8-1.9$ & 1.2 & 74.1 & 51.1 & 7.3 \\
\hline $1.9-2.0$ & 0.9 & 75.0 & 57.5 & 7.9 \\
\hline$>2.0$ & 25.0 & 100.0 & 83.3 & 26.7 \\
\hline
\end{tabular}

process. The sample of every coal material was analysed in the laboratory to determine the calorific value and ash content. Additionally, materials No. 1, 2, 4, and 5 were subjected to size and density distribution analysis.

Density distribution analyses were performed via floatsink tests using heavy liquids. The results indicated the washability of the coals, which facilitated the selection of optimal operating parameters for the NPPS. The test results for coal No. 1 in the grain-size class of $0-20 \mathrm{~mm}$ are presented in Table 1. Figure 4 presents washability curves based on the density distribution data in accordance with the equations presented in Table 2 (Blaschke 2009).

A densimetric analysis revealed that feed No. 1 in the 0-20 mm grain-size class could be considered an easily enrichable material: the content of grains with an intermediate density $\left(1.4-2.0 \mathrm{~g} / \mathrm{cm}^{3}\right)$ was only approximately $10 \%$ of the total sample weight. The ash content of the raw material was approximately $26 \mathrm{wt} \%$.

To determine the grain-size distribution, each coal sample was screened using square sieves. To determine the flakiness index for a given fraction, the samples screened on square sieves were then screened on bar sieves. Each grain-size class was sieved separately, using a sieve with a width equal to half of the upper class limit (PN-EN 933-3: 1999). The grain-size class of 0-4 mm was excluded from the tests. Table 3 presents the results of the flakiness-index analysis for coal No. 1. The grain-size distribution is presented as a bar plot in Fig. 5.

The size and density distribution analysis results for materials No. 2, 4, and 5 are presented in Online Resource 4 (Appendix D) $^{2}$.

${ }^{2}$ Data accessible at Mendeley data. https://doi.org/10.17632/ $57 \mathrm{f} 28 \mathrm{ph} 87 \mathrm{t} .1$

\section{Results}

In this section, the results of the separation tests are presented separately for the raw coal (as-received, pre-treated) and the waste materials originating from selected mines and coal dumps. The results are presented in form of graphs and tables. Owing to the large amount of data, most of them are presented in Online Resource 1 (Appendix A) ${ }^{3}$. Additionally, the results of supplementary tests related to the effects of the feed-material supply and properties on the process, are presented.

\subsection{Supplementary tests for initial optimisation}

\subsubsection{Optimal thickness of feed material layer}

The test results for four different layer-thickness variants of coal in the grain-size classes of 5-25 and 30-50 mm are presented in Table 4. The material was supplied by a conveyor belt, and the main-fan frequency remained unchanged throughout the tests. The suction efficiency, which was defined as the ratio of the amount of material sucked to the total amount fed, with respect to the layer thickness is presented in Fig. 6.

The results indicated that the layer thickness of the feed material significantly affected the suction efficiency. The suction efficiency tended to decrease as the layer thickness increased. The effect was more prominent for the grain-size class of 30-50 mm. Providing the material in the form of a layer with a thickness in the range of 1-1.5 times the maximum grain size for the given grain class resulted in a suction efficiency of $>90 \%$. Feeding more material caused a sharp decrease in the suction efficiency, probably owing to the significant reduction in the free flow of air between individual grains. Concurrently, the overall separation effectiveness decreased, as the grains that otherwise should

\footnotetext{
3 Data accessible at Mendeley data. https://doi.org/10.17632/ 57f28ph87t.1.
} 


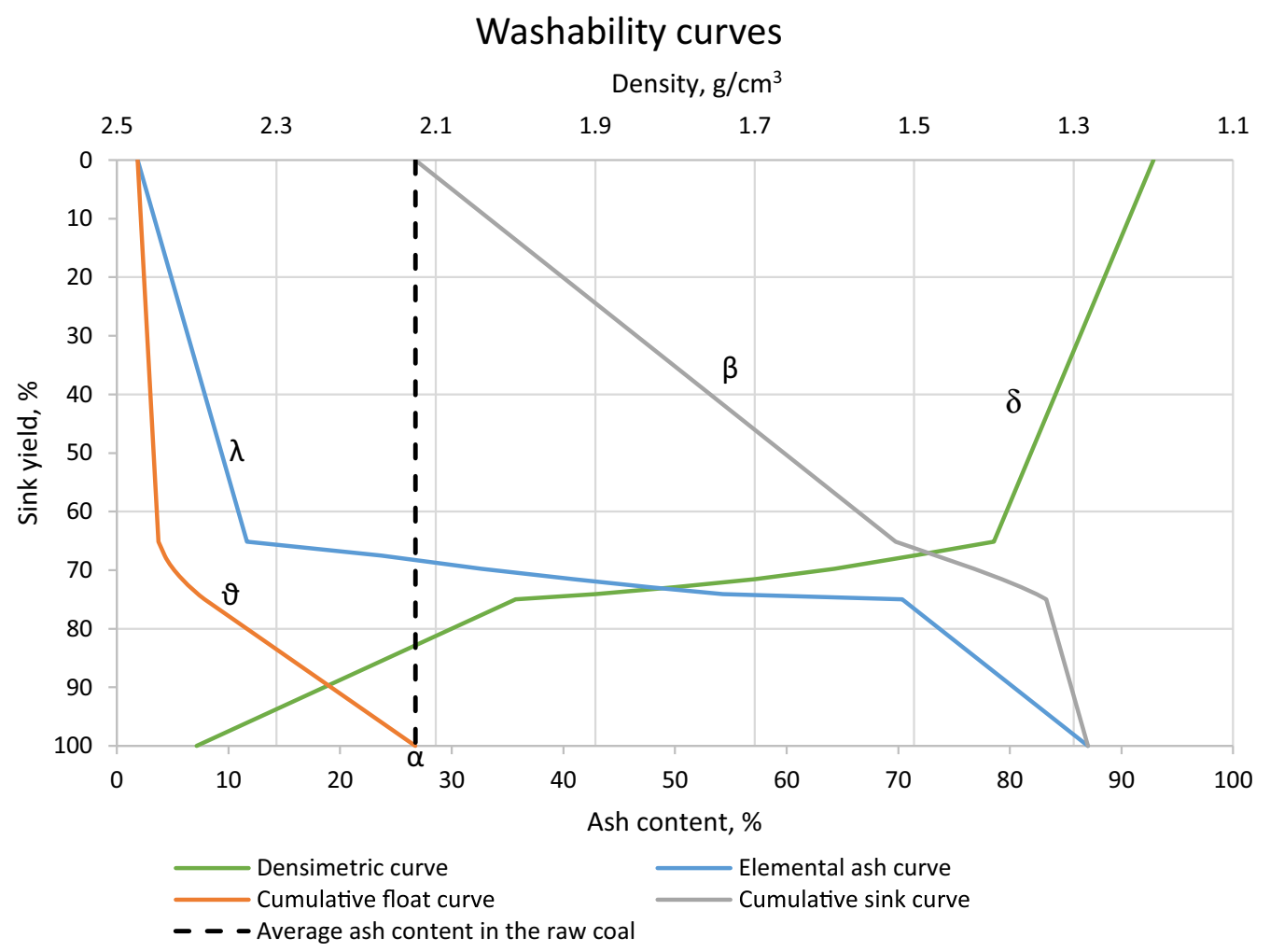

Fig. 4 Washability curves of material No. $1(0-20 \mathrm{~mm})$

Table 2 Density distribution of material No. 1 (grain-size class: $0-20 \mathrm{~mm}$ )

\begin{tabular}{ll}
\hline Curve coordinates & Equations \\
\hline Product yield & $\gamma_{n}^{k}=\sum_{1}^{n} \gamma_{n}$ \\
Waste yield & $\gamma_{n}^{o}=100-\sum_{1}^{n} \gamma_{n}$ \\
Ash content in the product & $\vartheta_{n}=\frac{\sum_{1}^{n} \gamma_{n} \cdot \lambda_{n}}{\sum_{1}^{n} \gamma_{n}}=\frac{\sum_{1}^{n} \gamma_{n} \cdot \lambda_{n}}{\gamma_{n}^{k}}$ \\
Ash content in the waste & $\beta_{n}=\frac{\sum_{1}^{n} \gamma_{n} \cdot \lambda_{n}}{100-\sum_{1}^{n} \gamma_{n}}=\frac{\sum_{1}^{n} \gamma_{n} \cdot \lambda_{n}}{\gamma_{n}^{o}}$ \\
Average ash content in the raw coal & $\alpha_{n}=\frac{\sum_{1}^{n} \gamma_{n} \cdot \lambda_{n}}{100}$ \\
\hline
\end{tabular}

have been sucked into the nozzle were constrained by the heavier particles above them. This effect was observed in additional separation tests, which resulted in lower-quality products at a similar output yield when material with a higher relative layer thickness was fed. The results are presented in Table 5 .

\subsubsection{Optimal speed of conveyor belt and rotary cylinder}

Tests were performed to evaluate the influence of the horizontal movement speed of the grains in the suction zone on the quality of the products (ash content). Each test was performed with different speeds of the conveyor belt and rotary cylinder, with the main fan adjusted such that the output yield was approximately maintained. The provided feed materials were raw coals in the grain-size class of $0-20 \mathrm{~mm}$. The results are presented in Table 6 .

For technical reasons, the examined speed range was limited to $1.5 \mathrm{~m} / \mathrm{s}$. A further increase in the conveyor-belt speed led to inconsistent feeding of the material into the suction zone; the results were thus considered non-representative and were omitted.

The gathered data indicated that separation performed at different feeding speeds resulted in products of similar quality. However, this conclusion is valid only for the examined range of the feeding speed, which was relatively narrow.

\subsubsection{Optimal position of suction nozzle}

Tests were performed on coal with an ash content of approximately $4 \mathrm{wt} \%$ in the grain-size class of $30-50 \mathrm{~mm}$ and on coal waste in the grain-size class of $10-30 \mathrm{~mm}$. The tests were performed with different speeds of the conveyor belt and the nozzle set at the $-5 \mathrm{~cm}$ " position, i.e. the nozzle front wall placed $5 \mathrm{~cm}$ from the cylinder axis in the conveyor-belt direction, or the " $+5 \mathrm{~cm}$ " position, i.e. the nozzle front wall placed $5 \mathrm{~cm}$ from the cylinder axis in 
Table 3 Sieving and flakiness-index analysis results for coal No. 1

\begin{tabular}{|c|c|c|c|c|c|}
\hline $\begin{array}{l}\text { Grain-size fraction } \\
(\mathrm{mm})\end{array}$ & $\begin{array}{l}\text { Fraction mass } \\
(\mathrm{g})\end{array}$ & $\begin{array}{l}\text { Yield } \\
(\%)\end{array}$ & $\begin{array}{l}\text { Cumulative yield } \\
(\%)\end{array}$ & $\begin{array}{l}\text { Nominal mesh size of bar sieves } \\
(\mathrm{mm})\end{array}$ & $\begin{array}{l}\text { Amount of material passed } \\
(\mathrm{g})\end{array}$ \\
\hline $40-50$ & 239 & 5.7 & 5.7 & 25 & 63 \\
\hline $31.5-40$ & 357 & 8.5 & 14.2 & 20 & 63 \\
\hline $25-31.5$ & 181 & 4.3 & 18.5 & 16 & 24 \\
\hline $20-25$ & 214 & 5.1 & 23.6 & 12.5 & 31 \\
\hline $16-20$ & 183 & 4.4 & 28.0 & 10 & 52 \\
\hline $12-16$ & 408 & 9.7 & 37.7 & 8 & 58 \\
\hline $10-12$ & 244 & 5.8 & 43.5 & 6 & 35 \\
\hline $8-10$ & 231 & 5.5 & 49.0 & 5 & 44 \\
\hline $6.3-8$ & 290 & 6.9 & 55.9 & 4 & 36 \\
\hline $4-6.3$ & 663 & 15.8 & 71.7 & 3 & 27 \\
\hline $0-4$ & 1188 & 28.3 & 100.0 & - & - \\
\hline Sum (4-50) & $M_{1}=3010$ & & & - & $M_{2}=433$ \\
\hline Flakiness index & & & & & Result \\
\hline \multirow[t]{3}{*}{$F I=\frac{M_{2}}{M_{1}} \cdot 100 \%$} & & & & & $F I_{0-20}=12.5 \%$ \\
\hline & & & & & $F I_{20-50}=18.3 \%$ \\
\hline & & & & & $F I_{0-50}=14.4 \%$ \\
\hline
\end{tabular}

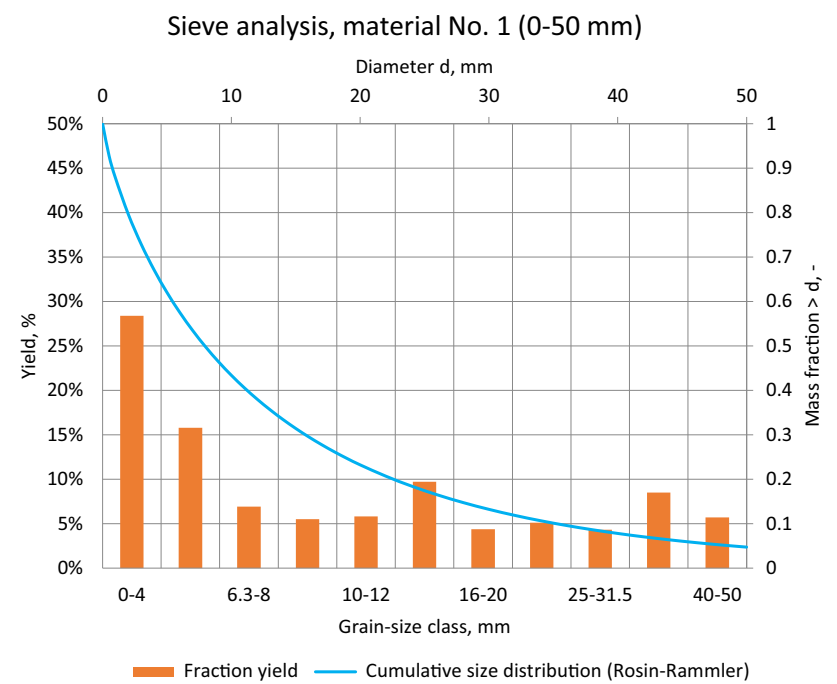

Fig. 5 Grain-size distribution for material No. 1

separator-frame direction. The test results are presented in Table 7.

Figure 7 shows the relationship between output yield of the sucked fraction and the linear velocity of the rotary cylinder, with the nozzle position set to " $-5 \mathrm{~cm}$ " or " $+5 \mathrm{~cm}$." Studies have indicated that increasing the rotation speed of the cylinder reduces the output yield. For the same fan speed, the output yield differed significantly depending on the suction nozzle position; it was higher with the nozzle positioned at " $-5 \mathrm{~cm}$ " than with the nozzle positioned at " $+5 \mathrm{~cm}$ ", for both the coal and coal waste materials. In the case of the " $+5 \mathrm{~cm}$ " position, the

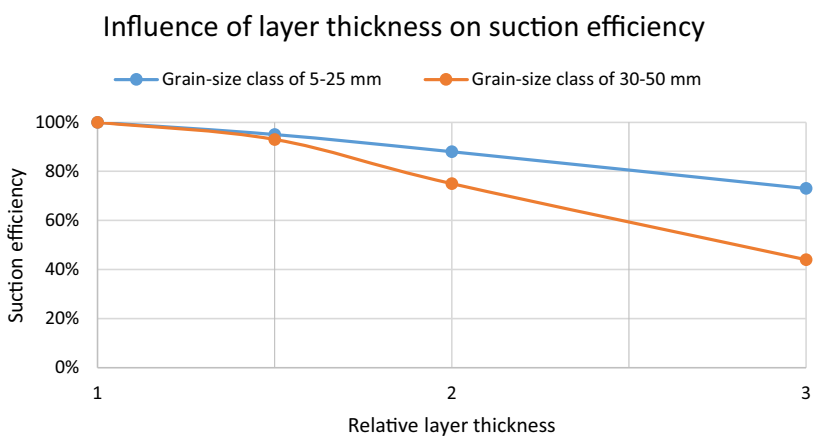

Fig. 6 Suction efficiency with respect to the relative layer thickness of the feed material

difference in the amount of sucked material due to the type was significantly smaller than that for the " $-5 \mathrm{~cm}$ " variant. This is an unfavourable phenomenon, as it limits the separation of coal and gangue grains.

According to the results of the supplementary tests, the optimal values of the work parameters of the device were determined as follows:

(1) conveyor belt speed, $0.5 \mathrm{~m} / \mathrm{s}$;

(2) scraper height, 1.5 multiplied by the largest grain diameter present in the feed being processed;

(3) position of the suction nozzle, “- $5 \mathrm{~cm}$ " configuration. 
Table 4 Suction efficiency of the feed material in different grain-size classes

\begin{tabular}{|c|c|c|c|c|c|}
\hline \multirow{2}{*}{$\begin{array}{l}\text { Speed of conveyor } \\
\text { belt }(\mathrm{m} / \mathrm{s})\end{array}$} & \multirow{2}{*}{$\begin{array}{l}\text { Relative layer thickness (x multiplied by the } \\
\text { maximum grain size) }\end{array}$} & \multicolumn{2}{|c|}{ Grain-size class of $5-25 \mathrm{~mm}$} & \multicolumn{2}{|c|}{ Grain-size class of $30-50 \mathrm{~mm}$} \\
\hline & & $\begin{array}{l}\text { Layer thickness } \\
(\mathrm{mm})\end{array}$ & $\begin{array}{l}\text { Suction } \\
\text { efficiency }(\%)\end{array}$ & $\begin{array}{l}\text { Layer thickness } \\
(\mathrm{mm})\end{array}$ & $\begin{array}{l}\text { Suction } \\
\text { efficiency }(\%)\end{array}$ \\
\hline \multirow[t]{4}{*}{0.5} & 1 & 25 & 100 & 50 & 100 \\
\hline & 1.5 & 38 & 95 & 75 & 93 \\
\hline & 2 & 50 & 88 & 100 & 75 \\
\hline & 3 & 75 & 73 & 150 & 44 \\
\hline
\end{tabular}

Table 5 Influence of the relative layer thickness on the effectiveness of the separation

\begin{tabular}{|c|c|c|c|c|}
\hline \multirow{2}{*}{$\begin{array}{l}\text { Main- } \\
\text { fan } \\
\text { setting } \\
(\mathrm{Hz})\end{array}$} & \multirow{2}{*}{$\begin{array}{l}\text { Relative layer } \\
\text { thickness (x } \\
\text { multiplied by the } \\
\text { maximum grain size) }\end{array}$} & \multicolumn{3}{|c|}{ Grain-size class of $5-25 \mathrm{~mm}$} \\
\hline & & $\begin{array}{l}\text { Output } \\
\text { yield } \\
(\%)\end{array}$ & $\begin{array}{l}\text { Sucked } \\
\text { fraction } \\
\text { ash } \\
\text { content } \\
(\%)\end{array}$ & $\begin{array}{l}\text { Non-sucked } \\
\text { fraction ash } \\
\text { content (\%) }\end{array}$ \\
\hline 32 & 1 & 72.7 & 14.1 & 52.1 \\
\hline 33 & 1.5 & 72.3 & 14.3 & 50.5 \\
\hline 34 & 2 & 71.4 & 14.9 & 46.7 \\
\hline 39 & 3 & 73.8 & 15.9 & 46.5 \\
\hline
\end{tabular}

\subsection{Effects of feed-material properties on suction efficiency}

To examine the effects of the feed-material properties on the suction efficiency, all the other work parameters of the device were set to the optimal values.

\subsubsection{Effects of grain properties on suction efficiency}

To evaluate the impact of each property, an in-depth analysis of the separation mechanism was performed, followed by air-flow velocity measurements and tests using materials with different physical properties.

The force exerted on the surface of a body moving through the air is given by the following formula (NASA Glenn Research Center 2015)

$F_{\mathrm{D}}=\frac{\rho_{\mathrm{a}} w_{\mathrm{a}}^{2}}{2} C_{\mathrm{D}} A$

where, $F_{\mathrm{D}}$ is drag force, $\mathrm{N} ; \rho_{\mathrm{a}}$ is mass density of the fluid (air), $\mathrm{kg} / \mathrm{m}^{3} ; w_{\mathrm{a}}$ is flow velocity relative to the object (air velocity), $\mathrm{m} / \mathrm{s} ; C_{\mathrm{D}}$ is drag coefficient; $A$ is the reference area (grain cross-sectional area), $\mathrm{m}^{2}$.

The drag coefficient is a sum of the friction and pressure drag components; however, for non-streamlined bodies, the friction drag has a miniscule impact and thus can be neglected. The pressure drag coefficient is most often determined experimentally and generally depends on the Reynolds number. At larger Reynolds numbers, the drag coefficients for most geometries essentially remain constant-in the range of 0.2 (for spheres) to approximately 1.1 (for thin disks) (Cengel and Cimbala 2018).

To determine whether a particle could be sucked into the suction nozzle under specific air-flow conditions, the equation for the terminal velocity can be used. When the air flows over the grain at a speed higher than the terminal velocity, the drag force overcomes the gravitational force,

Table 6 Influence of the material feeding speed on the separation

\begin{tabular}{|c|c|c|c|c|}
\hline \multirow{2}{*}{$\begin{array}{l}\text { Linear speed of conveyor belt and the rotary } \\
\text { cylinder }(\mathrm{m} / \mathrm{s})\end{array}$} & \multirow{2}{*}{$\begin{array}{l}\text { Main-fan setting } \\
(\mathrm{Hz})\end{array}$} & \multirow{2}{*}{$\begin{array}{l}\text { Output yield of sucked fraction } \\
(\%)\end{array}$} & \multicolumn{2}{|c|}{ Ash content (\%) } \\
\hline & & & $\begin{array}{l}\text { Sucked } \\
\text { fraction }\end{array}$ & $\begin{array}{l}\text { Non-sucked } \\
\text { fraction }\end{array}$ \\
\hline \multicolumn{5}{|l|}{ Material No. 1} \\
\hline 0.5 & 30 & $76.8^{*}$ & $21.5^{*}$ & $38.3^{*}$ \\
\hline 1.0 & 30.5 & 77.6 & 21.8 & 40.1 \\
\hline 1.5 & 31 & 76.9 & 21.3 & 39.1 \\
\hline \multicolumn{5}{|l|}{ Material No. 2} \\
\hline 0.5 & 30 & 76.9 & 21.3 & 43.2 \\
\hline 1.0 & 30.5 & 76.9 & 21.5 & 43.9 \\
\hline 1.5 & 31 & 76.7 & 21.9 & 44.9 \\
\hline
\end{tabular}

*Data based on results of main experiments 


\section{Suction efficiency with different nozzle positions}

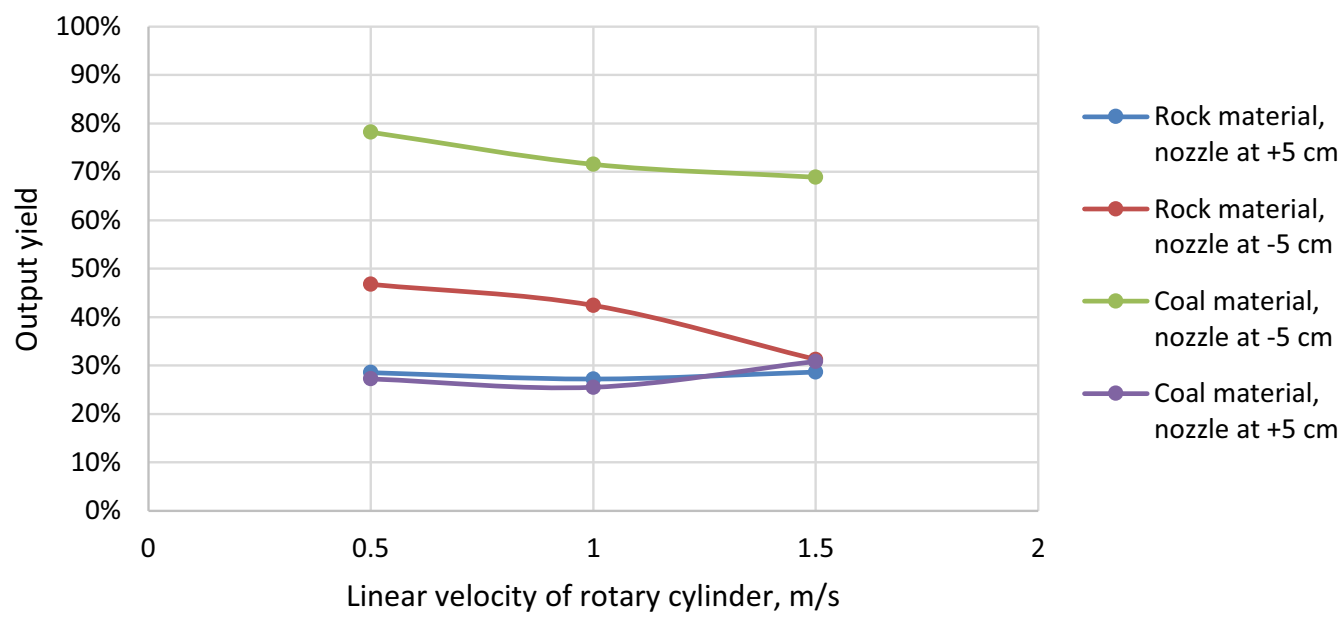

Fig. 7 Sucked-fraction output yield with respect to the linear velocity of the cylinder for different suction nozzle positions

Table 7 Suction efficiency of grains with respect to the speed of the conveyor belt and the nozzle position

\begin{tabular}{|c|c|c|c|c|}
\hline $\begin{array}{l}\text { Type of } \\
\text { material }\end{array}$ & $\begin{array}{l}\text { Grain-size } \\
\text { class }(\mathrm{mm})\end{array}$ & $\begin{array}{l}\text { Linear speed of the conveyor belt and } \\
\text { rotary cylinder }(\mathrm{m} / \mathrm{s})\end{array}$ & $\begin{array}{l}\text { Suction efficiency, nozzle } \\
\text { positioned at }-5 \mathrm{~cm}(\%)\end{array}$ & $\begin{array}{l}\text { Suction efficiency, nozzle } \\
\text { positioned at }+5 \mathrm{~cm}(\%)\end{array}$ \\
\hline \multirow[t]{3}{*}{ Coal } & \multirow[t]{3}{*}{$30-50$} & 0.5 & 79.8 & 28.3 \\
\hline & & 1.0 & 63.6 & 25.0 \\
\hline & & 1.5 & 64.8 & 14.9 \\
\hline \multirow[t]{3}{*}{ Waste } & \multirow[t]{3}{*}{$10-30$} & 0.5 & 46.7 & 28.5 \\
\hline & & 1.0 & 42.4 & 27.2 \\
\hline & & 1.5 & 31.3 & 20.7 \\
\hline
\end{tabular}

and the grain begins to accelerate upwards. The formula for the terminal velocity-not considering buoyancy effectsis as follows (NASA Glenn Research Center 2018)

$w_{\mathrm{a}, \mathrm{t}}=\sqrt{\frac{2 m g}{\rho_{\mathrm{a}} C_{\mathrm{D}} A}}$

where, $m$ is the body mass, $\mathrm{kg} ; \rho_{\mathrm{a}}$ is mass density of the fluid (air), $\mathrm{kg} / \mathrm{m}^{3} ; \mathrm{g}$ is the gravitational acceleration, $\mathrm{m} / \mathrm{s}^{2}$ is

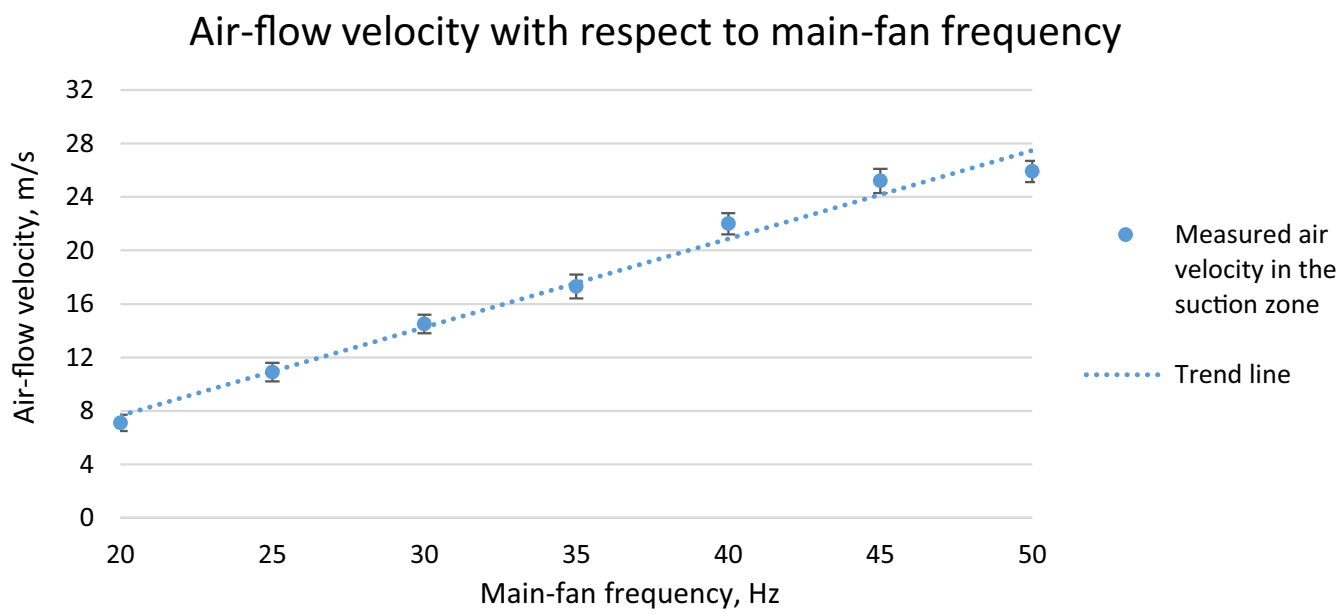

Fig. 8 Measurement results for the air-flow velocity with respect to the main-fan frequency 
Table 8 Effects of the grain properties on the suction efficiency

\begin{tabular}{|c|c|c|c|c|c|}
\hline Item & Density $\left(\mathrm{kg} / \mathrm{m}^{3}\right)$ & Diameter $(\mathrm{mm})$ & Shape & Fan setting $(\mathrm{Hz})$ & Air-flow velocity* $(\mathrm{m} / \mathrm{s})$ \\
\hline \multirow[t]{2}{*}{ Juxtaposition 1} & 1320 & $8-10$ & Cubic & 29 & 13.9 \\
\hline & 2475 & & & 38 & 20.0 \\
\hline \multirow[t]{2}{*}{ Juxtaposition 2} & 1320 & $4-6,3$ & Cubic & 25 & 10.9 \\
\hline & & $16-20$ & & 38 & 20.0 \\
\hline \multirow[t]{2}{*}{ Juxtaposition 3} & 2475 & $16-20$ & Cubic & 50 & 26.5 \\
\hline & & & Flat & 34 & 17.5 \\
\hline
\end{tabular}

*Calculated according to the trend line (Fig. 8)

the drag coefficient; $A$ is the reference area (grain crosssectional area), $\mathrm{m}^{2}$.

Figure 8 shows the results for the air-velocity measurements in the suction zone. The equation of the trend line relates the air velocity to the main-fan frequency.

The main-fan setting values (along with the corresponding air flow rates in the suction zone) at which the material was completely sucked in for samples with different physical properties are presented in Table 8. Each of the three considered material parameters affected the pneumatic separation process; however, their impacts differed. The experimental results differed from those predicted using the terminal velocity formula. This was due to the specifics of the device's operation (the feeding of the material into the suction zone introduced a horizontal velocity vector, increasing the flow speed required for suction owing to the limited residence time of the particle in the suction zone), as well as the actual parameters of the feed (in practice, the grains present in the feed have various shapes, ranging from an ideal sphere to a thin disk).

\subsubsection{Effects of feed moisture content on amount of material sucked by suction nozzle and into main- fan channel}

To determine the influence of the water content in the feed material on the suction efficiency and the amount of material sucked into the main-fan air duct, a series of experiments was performed using wetted, naturally moist (as-received), and air-dried raw coal. Material No. 2 was employed. The "wetted" sample was obtained via addition of approximately $5 \mathrm{wt} \%$ of water. The test results are presented in Table 9.

The results indicated that the difference in the suction efficiency between the naturally moist and dry materials was small. However, for the wetted material, the suction efficiency was significantly lower. This was probably due to the grains sticking together, which limited the possibility of air flowing between individual grains. It can be inferred that for a given feed material, the maximum moisture content at which the process is viable can be determined. This value would probably lie in the range of $12 \%-20 \%$, as is the case for other dry separation methods (Baic et al. 2016).

The amount of fine-grained material sucked into the air duct increased with the fan speed. The effect was more noticeable for the air-dried feed material.

Sieving off the smallest grains $(0-5 \mathrm{~mm}$ diameter) reduced the material loss by $>50 \%$.

\subsection{Results of main experiments}

To examine the effects of the main-fan suction force on the quality and yield of the products, all the other work parameters of the device were set to the optimal values.

\subsubsection{Effects of main-fan setting on hard-coal separation}

Each feed material was processed with different device work parameters. Among the parameters, the fan speed had the most significant effect on the properties of the products; therefore, its influence was studied thoroughly. Numerous trials were performed for each of the prepared feed materials, resulting in different rates of the product yield and properties, such as the calorific value and ash content. Eight different raw coals were tested (samples No. 1-8).

The complete results are presented in Online Resource 3 (Appendix C) ${ }^{4}$. Because the observed effect of the fan speed was similar for all the materials processed, the results presented in this part cover only the tests performed on feed material No. 1. The output yields of the sucked fractions and their LCVs are presented in Table 10 for three different grain-size classes.

The results indicated that increasing the fan speed increased the sucked-fraction output yield; however, it reduced the LCV. The output yield can be adjusted in accordance with the required minimal calorific value.

\footnotetext{
${ }^{4}$ Data accessible at Mendeley data. https://doi.org/10.17632/ 57f28ph87t.1.
} 
Table 9 Effects of feed moisture content on the suction efficiency and dust collector load

\begin{tabular}{|c|c|c|c|c|c|c|c|}
\hline \multirow[b]{2}{*}{ Grain-size class (mm) } & \multirow[b]{2}{*}{ Moisture content } & \multicolumn{3}{|c|}{$\begin{array}{l}\text { Part of material sucked by the suction nozzle } \\
(\text { wt } \%)\end{array}$} & \multicolumn{3}{|c|}{$\begin{array}{l}\text { Part of material sucked into the air duct } \\
(\mathrm{wt} \%)\end{array}$} \\
\hline & & $32 \mathrm{~Hz}$ & $34 \mathrm{~Hz}$ & $36 \mathrm{~Hz}$ & $32 \mathrm{~Hz}$ & $34 \mathrm{~Hz}$ & $36 \mathrm{~Hz}$ \\
\hline \multirow[t]{3}{*}{$0-20$} & "Wetted", $W_{\mathrm{w}} \approx 15.92 \%$ & 67.7 & 71.8 & 75.8 & 0.08 & 0.08 & 0.09 \\
\hline & As-received, $W_{\mathrm{t}}^{\mathrm{r}}=11.72 \%$ & $81.9 *$ & $88.9 *$ & $91.8 *$ & 0.18 & 0.22 & 0.28 \\
\hline & Air-dried, $W^{\mathrm{a}}=7.51 \%$ & 82.2 & 90.3 & 91.6 & 0.44 & 0.50 & 0.60 \\
\hline \multirow[t]{3}{*}{$5-20$} & "Wetted", $W_{\mathrm{w}} \approx 14.94 \%$ & 59.2 & 65.8 & 69.7 & 0.03 & 0.03 & 0.04 \\
\hline & As-received, $W_{\mathrm{t}}^{\mathrm{r}}=10.69 \%$ & $66.6^{*}$ & $75.8^{*}$ & $79.6^{*}$ & 0.12 & 0.12 & 0.16 \\
\hline & Air-dried, $W^{\mathrm{a}}=7.58 \%$ & 68.1 & 76.3 & 80.6 & 0.16 & 0.20 & 0.38 \\
\hline
\end{tabular}

*Data based on the results of the main experiments

Feed material No. 1, output yield $70 \%-75 \%$

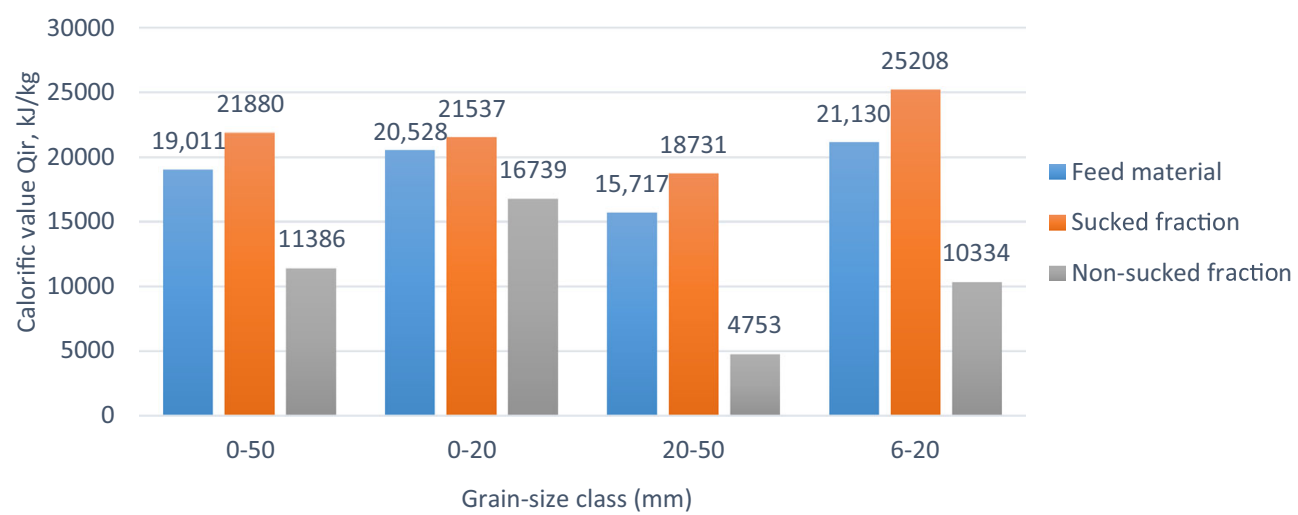

Fig. 9 Calorific value of each fraction for different grain-size classes (feed material No. 1)

\section{Feed material No. 1, output yield $70 \%-75 \%$}

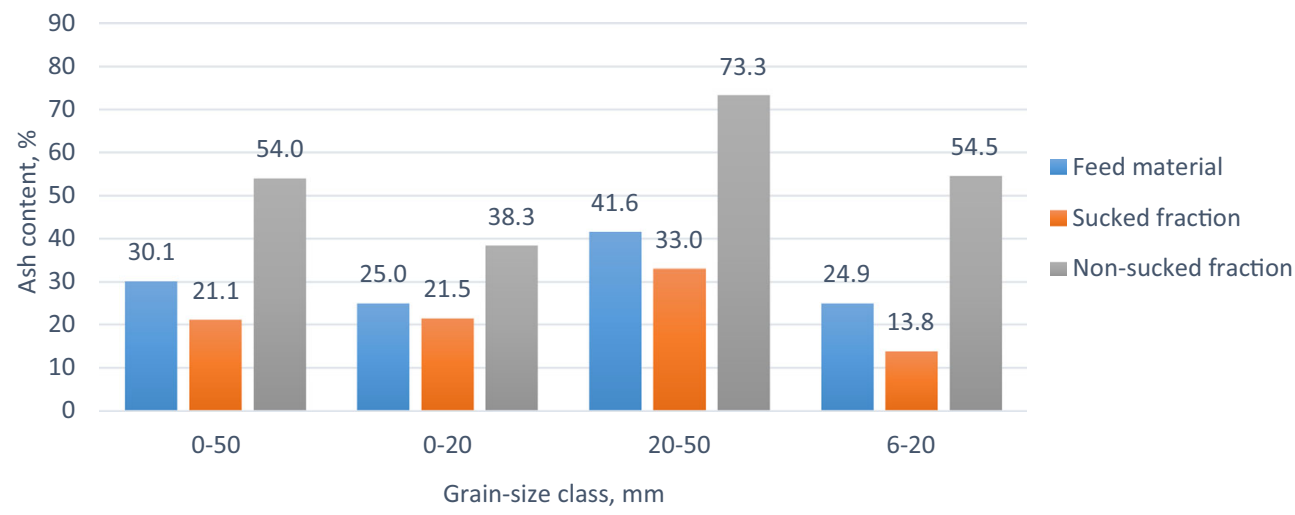

Fig. 10 Ash content in each fraction for different grain-size classes (feed material No. 1) 
Table 10 Output yield (Y), LCV, and ash content of the sucked fraction, for feed material No. 1

\begin{tabular}{|c|c|c|c|c|c|c|c|c|c|}
\hline \multirow[t]{2}{*}{ Suction fan setting $(\mathrm{Hz})$} & \multicolumn{3}{|c|}{ Grain-size class $0-20 \mathrm{~mm}$} & \multicolumn{3}{|c|}{ Grain-size class $0-50 \mathrm{~mm}$} & \multicolumn{3}{|c|}{ Grain-size class $20-50 \mathrm{~mm}$} \\
\hline & $\mathrm{Y}(\%)$ & $\mathrm{LCV}(\mathrm{kJ} / \mathrm{kg})$ & Ash $(\%)$ & $\mathrm{Y}(\%)$ & $\mathrm{LCV}(\mathrm{kJ} / \mathrm{kg})$ & Ash $(\%)$ & $\mathrm{Y}(\%)$ & $\mathrm{LCV}(\mathrm{kJ} / \mathrm{kg})$ & Ash $(\%)$ \\
\hline - & 100 & 20528 & 25.0 & 100 & 19011 & 30.1 & 100 & 15717 & 41.6 \\
\hline 30 & 76.8 & 21537 & 21.5 & & & & & & \\
\hline 34 & 89.9 & 21641 & 21.8 & & & & & & \\
\hline 36 & 94.8 & 21622 & 21.4 & & & & & & \\
\hline 38 & & & & 72.8 & 21880 & 21.1 & & & \\
\hline 42 & & & & 82.2 & 21490 & 23.5 & 36.3 & 26579 & 11.4 \\
\hline 46 & & & & 86.1 & 20439 & 24.9 & 60.9 & 23839 & 18.5 \\
\hline 50 & & & & & & & 69.6 & 18731 & 33.0 \\
\hline
\end{tabular}

Similar tendencies were observed for every feed material tested. However, the exact calorific values varied depending on the raw-material properties.

\subsubsection{Raw coal separation process under optimal work parameters}

The results of tests with the optimal work parameters were evaluated to determine the processability of selected feed materials originating from different coal mines. The results had to satisfy the following criteria:

(1) sucked-fraction output yield of $>60 \%$;

(2) output yields of compared materials deviate by $<10 \%$.

had to satisfy the following criteria

Figures 9 and 10 present the LCV and ash content of each fraction for different grain-size classes for the tests performed on feed material No. 1 with the optimal work parameters.

The results indicated that the exact calorific value of the sucked fraction was significantly dependent on the properties of the feed material and whether it had been previously pre-treated. For example, processing of $0-20 \mathrm{~mm}$ feed material No. 2 (LCV of approximately $16,000 \mathrm{~kJ} / \mathrm{kg}$ ) resulted in a product with an LCV of approximately $19,000 \mathrm{~kJ} / \mathrm{kg}$, whereas for material No. $6(20,000 \mathrm{~kJ} / \mathrm{kg})$ in the same grain-size class, the sucked fraction was characterised by an LCV of approximately $23,000 \mathrm{~kJ} / \mathrm{kg}$. It can be inferred that the calorific value of the product may increase by $5 \%-40 \%$ compared with that of the feed material.

Among the grain-size classes, 0-20 mm was the least amenable to pneumatic separation-even the raw 0-50 mm class performed better. The class of $20-50 \mathrm{~mm}$ exhibited the best results, i.e. the calorific value of the sucked fraction increased significantly, even as non-sucked fraction calorific value decreased below $5000 \mathrm{~kJ} / \mathrm{kg}$. The grain-size class of 6-20 $\mathrm{mm}$ exhibited the second-best results-eliminating the smallest grains significantly improved the process performance.

In every test, the sucked fraction had a lower ash content than the feed material. This effect was the most and least prominent for the grain-size classes of $20-50 \mathrm{~mm}$ and 0-20 mm, respectively. However, removing the smallest grains $(0-6 \mathrm{~mm})$ was sufficient for improving the process considerably.

The non-sucked fraction was characterised by a relatively low ash content, which is unfavourable. Only a few tests resulted in a non-sucked fraction with an ash content of $>80 \%$ (typically for the $20-50 \mathrm{~mm}$ class). It appeared that this fraction would have to be subjected to further enrichment via other methods. Alternatively, it could be used for fuel production as a component reducing its overall calorific value.

Comparisons between the test results for different feed materials are presented in Figs. 11, 12, 13, 14, 15 and 16. The differences in the ash content and LCV among the grain-size classes are shown. Significant differences were observed in the process effectiveness depending on the feed material used. The results indicate the processability of the different materials in the context of pneumatic separation.

3.3.2.1 Grain-size class of $0-50 \mathrm{~mm}$ For the grain-size class of 0-50 mm, the best results were obtained with feed materials No. 4, 6, and 7. The processing of coal No. 4 increased its LCV by approximately $6000 \mathrm{~kJ} / \mathrm{kg}$. The least favourable results were obtained with raw coals Nos. 3 and 5: the LCV increased by approximately $2000 \mathrm{~kJ} / \mathrm{kg}$. Regarding the product quality, the processing of material No. 7 resulted in the non-sucked fraction with the highest ash content $(>80 \%)$. 


\section{Grain-size class 0-50 mm, output yield 80\%-85\%}

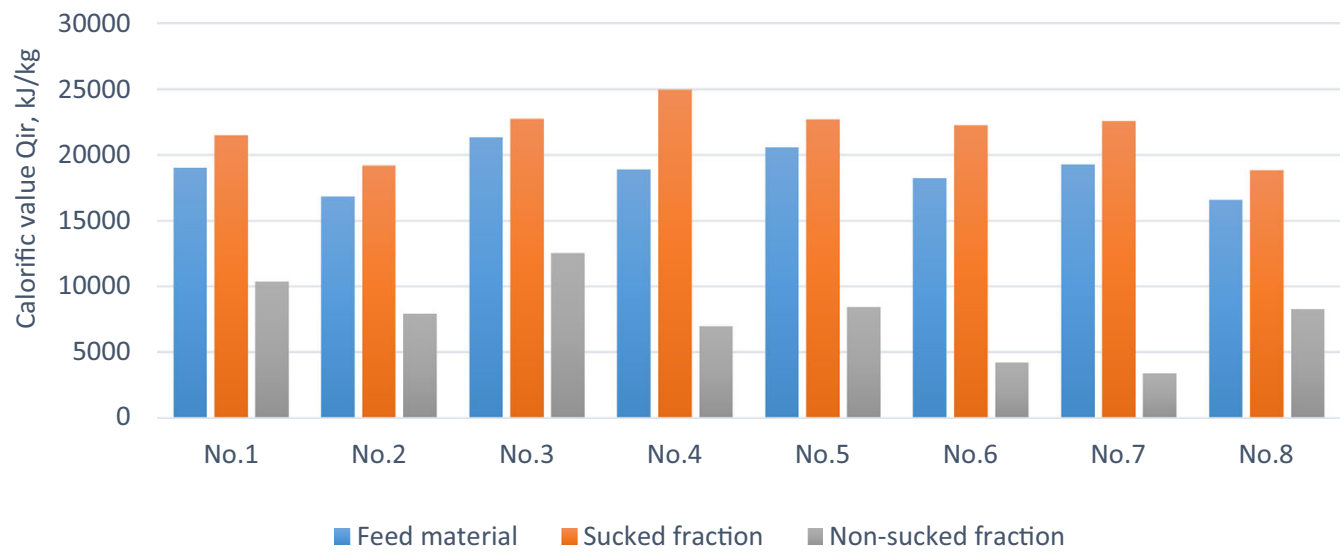

Fig. 11 Calorific value with respect to the origin of the feed material (grain-size class of 0-50 mm)

\section{Grain-size class 0-50 mm, output yield $80 \%-85 \%$}

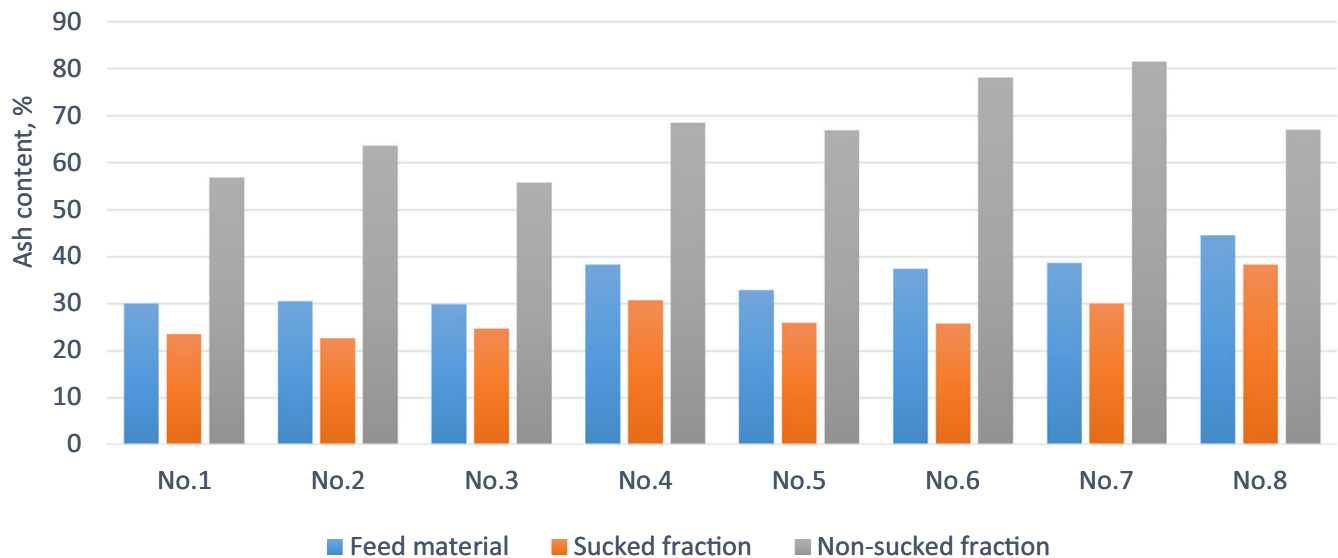

Fig. 12 Ash content with respect to the origin of the feed material (grain-size class of 0-50 mm)

\section{Grain-size class 0-20 mm, output yield $80 \%-85 \%$}

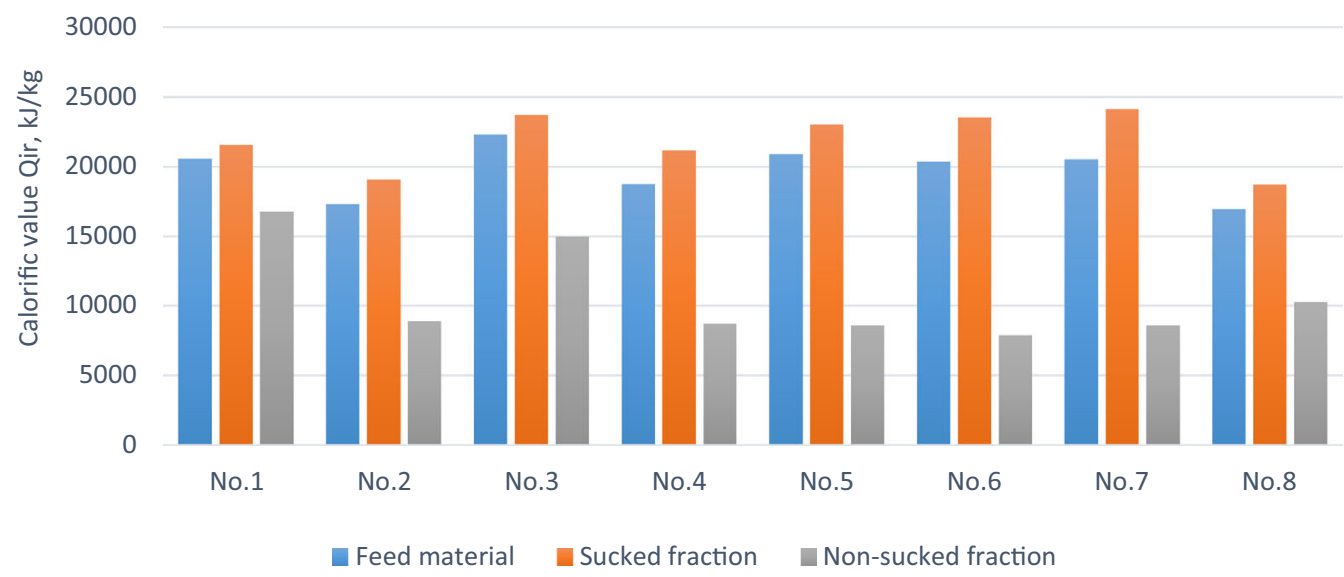

Fig. 13 Calorific value with respect to the origin of the feed material (grain-size class of 0-20 mm) 


\section{Grain-size class 0-20 mm, output yield 80\%-85\%}

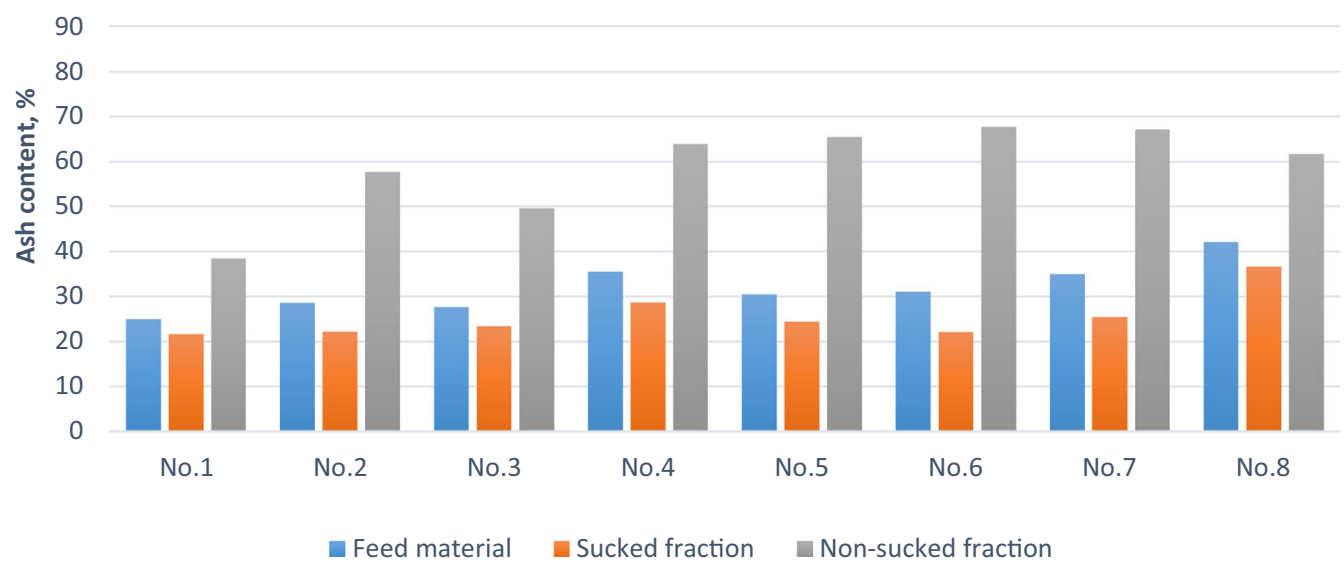

Fig. 14 Ash content with respect to the origin of the feed material (grain-size class of 0-20 mm)

\section{Grain-size class $20-50 \mathrm{~mm}$, output yield $65 \%-75 \%$}

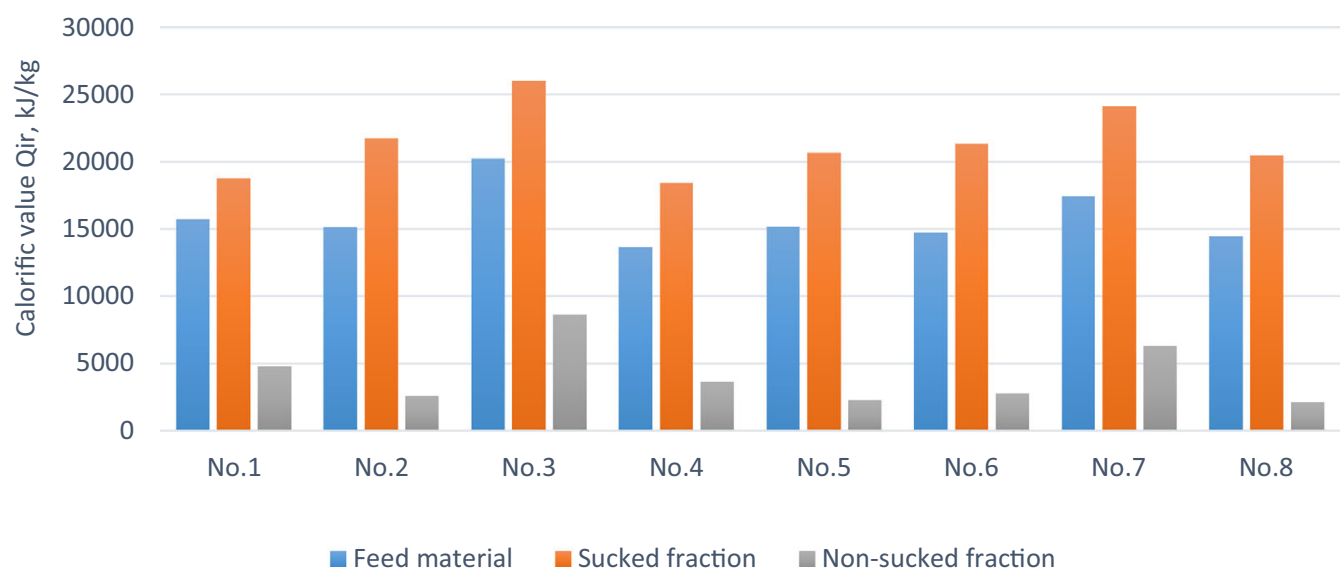

Fig. 15 Calorific value with respect to the origin of the feed material (grain-size class of 20-50 mm)

\section{Grain-size class $20-50 \mathrm{~mm}$, output yield $65 \%-75 \%$}

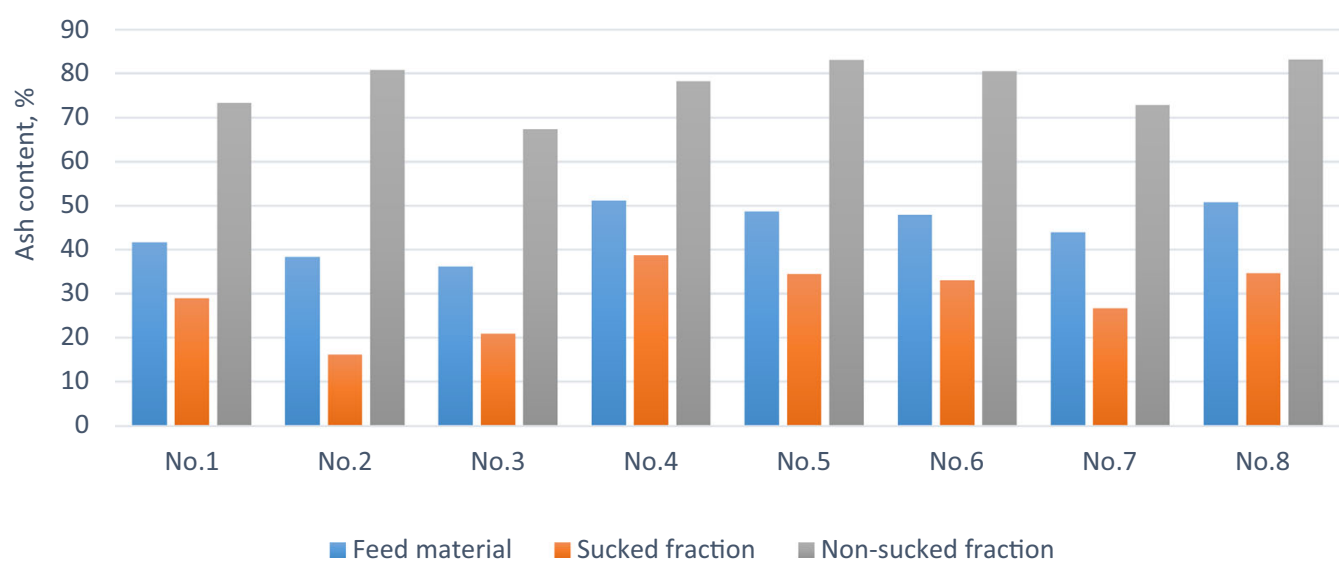

Fig. 16 Ash content with respect to the origin of the feed material (grain-size class of $20-50 \mathrm{~mm}$ ) 
3.3.2.2 Grain-size class of $0-20 \mathrm{~mm}$ For the tests with pre-treated materials sieved into the $0-20 \mathrm{~mm}$ class, the separation of raw coals No. 6 and 7 yielded the best results. The LCV of the obtained products was approximately $24,000 \mathrm{~kJ} / \mathrm{kg}$ - an increase of 3000-4000 kJ/kg compared with the raw feed material. The separation performance was the worst for samples No. 1, 2, and 8. The non-sucked fraction ash content was relatively low-it exceeded $60 \%$ only in half of the cases.

3.3.2.3 Grain-size class of $20-50 \mathrm{~mm}$ The best overall performance was observed for the experiments with the 20-50 mm grain-size class. The increase in the LCV, relative to the feed material, ranged from 3000 to almost $7000 \mathrm{~kJ} / \mathrm{kg}$. For most of the samples, the LCV of the obtained products was greater than $20,000 \mathrm{~kJ} / \mathrm{kg}$, and in some cases, the LCV exceeded $24,000 \mathrm{~kJ} / \mathrm{kg}$. The highestquality product was obtained for the processing of feeds No. 5 and 8, i.e. material with an ash content of more than $80 \%$.

\subsubsection{Coal waste material separation}

The study on the separation process of coal waste materials was conducted to evaluate the possibility of obtaining useful products from non-sintered waste generated during coal processing and stored at coal dumps. Two different materials originating from Silesian coal-waste dumps were tested (samples No. 9, 10). The effectiveness of the process was determined by comparing the ash content of the feed material and the product obtained through separation. The results are presented in Table 11.

The tests indicated that pneumatic separation is effective for the beneficiation of coal wastes originating from the wet enrichment processes. The results indicated the possibility of a $10 \%-25 \%$ decrease in the ash content of the sucked fraction compared with the feed material. The main advantage of the sorter is its mobility: it can be moved to the coal-waste dump and can execute the process directly at the landfill, thereby limiting the material-transport costs.

Even if another enrichment method is required after the pneumatic separation, the amount of material that must be transported is reduced.

\subsubsection{Measurement uncertainties}

The measurement uncertainties were calculated according to the accuracy of the instruments that were used, the defined laboratory uncertainties, and the estimated experimental errors.

Characteristics of used measuring devices:
(1) Anemometer $\pm(0.2 \mathrm{~m} / \mathrm{s}+1 \%$ measured value $)$ in range of $0.6-40 \mathrm{~m} / \mathrm{s}$; resolution of $0.1 \mathrm{~m} / \mathrm{s}$

(2) Scales $\pm(0.01 \mathrm{~kg}+1 \%$ measured value $)$ in range of $1-40 \mathrm{~kg}$; resolution of $0.01 \mathrm{~kg}$

Characteristics of used measuring devices

The results of the air-flow velocity measurements are presented in Table 12.

The majority of the coal separation tests were performed for individual samples; thus, it was impossible to determine the type A measurement uncertainty. To determine the standard deviation of the tested quantities, i.e. the output yield and ash content of each fraction, additional separation tests were performed using coal in the grain class of 6-25 mm with a fixed main-fan setting. It was concluded that, owing to the consistent research methodology, the measurement uncertainty estimated in this manner can be adopted for all the tests performed.

The value of $\Delta \mathrm{d}_{x}$ for the output yield resulted from the characteristics of the laboratory scales used, and the $\Delta \mathrm{d}_{x}$ for the ash content was given by the laboratory test results. The investigator uncertainty values $\Delta \mathrm{e}_{x}$ for the output yield were assumed to be $0.5 \%$ and were attributed to the partial suction of the material into the fan duct. The $\Delta \mathrm{e}_{x}$ for the ash content was related to the research methodology. The large variability of the results was due to factors such as the varied physicochemical parameters of the samples (even for samples from the same mine), non-ideal pre-treatment of the samples, small number of samples, and imperfect sampling for laboratory testing. The results of the measurement uncertainty assessment for the output yield and ash content are presented in Table 13 .

\section{Discussion}

The experimental results indicated that the method of feeding the material into the suction zone is a key factor influencing the separation process. It is best to feed material in the state of a loose layer, so that the grains can move freely. A monolayer, which is regarded as a layer with a thickness approximately equal to the upper grain-size class limit, should be considered as the maximum allowed for optimal operation. Increasing the layer thickness above this limit may hinder the separation process, reducing the product quality. While a thicker layer corresponds to a larger amount of material processed, the decrease in the suction efficiency reduces this potential gain.

The tests indicated that the linear speed of the conveyor belt and the rotary cylinder in the range of $0.5-1.5 \mathrm{~m} / \mathrm{s} \mathrm{did}$ not significantly affect the product quality. An increase in the speed translates directly into a larger amount of material processed. However, to keep the output yield of 
Table 11 Ash content of the feed material (coal waste) and sucked fraction

\begin{tabular}{|c|c|c|c|c|}
\hline \multirow[t]{3}{*}{ Main suction fan setting $(\mathrm{Hz})$} & \multicolumn{4}{|c|}{ Coal waste No. 9, grain-size class of $0-20 \mathrm{~mm}$} \\
\hline & \multirow[t]{2}{*}{ Sucked-fraction output yield (wt $\%$ ) } & \multicolumn{3}{|c|}{ Ash content (wt\%) } \\
\hline & & Sucked fraction & Non-sucked fraction & Feed material \\
\hline 30 & 9.5 & 58.1 & 81.2 & 78.9 \\
\hline 34 & 31.1 & 70.2 & 83.0 & \\
\hline 36 & 43.3 & 74.5 & 82.4 & \\
\hline \multirow[t]{3}{*}{ Main suction fan setting $(\mathrm{Hz})$} & \multicolumn{4}{|c|}{ Coal waste No. 10 , grain-size class of $0-20 \mathrm{~mm}$} \\
\hline & \multirow[t]{2}{*}{ Sucked-fraction output yield (wt\%) } & \multicolumn{3}{|c|}{ Ash content (wt\%) } \\
\hline & & Sucked fraction & Non-sucked fraction & Feed material \\
\hline 30 & 4.5 & 65.2 & 87.0 & 86.1 \\
\hline 32 & 14.7 & 73.1 & 88.2 & \\
\hline 34 & 26.3 & 78.1 & 88.8 & \\
\hline
\end{tabular}

Table 12 Measured air-flow velocity in the suction zone, for assessment of the measurement uncertainty

\begin{tabular}{|c|c|c|c|c|c|c|c|c|c|c|c|}
\hline \multirow[b]{2}{*}{ Main-fan setting $(\mathrm{Hz})$} & \multicolumn{7}{|c|}{ Measured air-flow velocity (m/s) } & \multicolumn{4}{|l|}{ Uncertainty calculation } \\
\hline & 1 & 2 & 3 & 4 & 5 & 6 & Mean value $\bar{w}$ & $\operatorname{SD} u(w) ; t_{\alpha=0.317, n=5}=1.11$ & $\Delta \mathrm{d}_{x}$ & $\Delta \mathrm{e}_{x}$ & $u_{\mathrm{c}}(w)$ \\
\hline 20 & 6.8 & 7.1 & 6.5 & 7.1 & 6.9 & 8 & 7.1 & 0.6 & 0.3 & 0.2 & 0.6 \\
\hline 25 & 9.9 & 10.4 & 11.1 & 11.4 & 11.6 & 10.7 & 10.9 & 0.7 & 0.3 & 0.2 & 0.7 \\
\hline 30 & 14.1 & 14.9 & 14.2 & 14 & 15.6 & 13.9 & 14.5 & 0.7 & 0.3 & 0.3 & 0.8 \\
\hline 35 & 16.3 & 18.5 & 16.7 & 17 & 17.5 & 17.7 & 17.3 & 0.9 & 0.4 & 0.3 & 0.9 \\
\hline 40 & 21.8 & 21.1 & 22 & 21.6 & 22.2 & 23.2 & 22.0 & 0.8 & 0.4 & 0.4 & 0.9 \\
\hline 45 & 25.8 & 25 & 24.1 & 24.5 & 25.5 & 26.1 & 25.2 & 0.9 & 0.5 & 0.4 & 0.9 \\
\hline 50 & 26.6 & 25 & 25.5 & 25.2 & 26.7 & 26.2 & 25.9 & 0.8 & 0.5 & 0.5 & 0.9 \\
\hline
\end{tabular}

Table 13 Results of laboratory tests together with the calculated measurement uncertainties (coal samples in the grain-size class of 6-25 mm)

\begin{tabular}{|c|c|c|c|c|c|c|c|c|c|c|c|}
\hline \multirow[t]{3}{*}{ Measured parameter } & \multicolumn{11}{|c|}{ Uncertainty assessment of proximate analysis } \\
\hline & \multicolumn{7}{|c|}{ Value for a given sample $(\%)$} & \multicolumn{4}{|l|}{ Uncertainty calculation } \\
\hline & 1 & 2 & 3 & 4 & 5 & 6 & Mean value & $\mathrm{SD} u(w) ; t_{\alpha=0.317, n=5}=1.11$ & $\Delta \mathrm{d}_{x}$ & $\Delta \mathrm{e}_{x}$ & $u_{\mathrm{c}}(x)$ \\
\hline Output yield & 58.1 & 60.0 & 60.4 & 64.0 & 67.5 & 65.7 & 62.6 & 4.1 & 1.0 & 0.5 & 4.1 \\
\hline Ash content, sucked fraction & 11.4 & 12.4 & 12.7 & 13.1 & 21.8 & 21.3 & 15.5 & 5.4 & 0.22 & 2 & 5.5 \\
\hline Ash content, non-sucked fraction & 41.6 & 47.0 & 42.0 & 42.2 & 29.5 & 29.2 & 38.6 & 8.2 & 0.15 & 2 & 8.3 \\
\hline
\end{tabular}

the sucked fraction at a constant level, the fan's operating frequency should be increased. For technical reasons, the speed of the conveyor belt should not exceed $1.5 \mathrm{~m} / \mathrm{s}-\mathrm{a}$ further increase resulted in inconsistent feeding of the material into the suction zone of the device in its present form.

The positioning of the suction nozzle was relevant in the process as well. 
The " $-5 \mathrm{~cm}$ " setting, in which the nozzle front wall was moved $5 \mathrm{~cm}$ from the cylinder axis towards the conveyor belt, was superior to the " $+5 \mathrm{~cm}$ " variant; it resulted in a higher output yield and better selectiveness for coal and gangue separation.

The moisture content of the feed affects the separation efficiency by changing the physical properties of the material fed into the device. Above a certain moisture content, the grains may clump together. This phenomenon is always disadvantageous from the viewpoint of the separation efficiency and causes technical problems in the device. Thus, the moisture content of the feed intended for separation should be within the range allowing for an undisturbed separation process, i.e. not causing clumping of the feed grains. Materials that do not satisfy this condition can be pre-treated by first reducing the moisture content or removing the fraction that causes the grains to clump, e.g. the smallest grains $(0-5 \mathrm{~mm})$. The results indicated that the natural moisture content present in the tested raw coals did not impair the separation process. In contrast, it reduced the amount of material sucked into the air duct, thus reducing the material loss and dust-collector load.

The experimental results indicated that the effects of other material properties were consistent with Eq. (3); i.e. the change in the terminal velocity of the grain in the suction zone was proportional to the square root of the change in value of a given physical property, in accordance with the following relationships.

(1) For density: $\frac{w_{a, g, 1}}{w_{a, g, 2}} \approx \sqrt{\frac{m_{1}}{m_{2}}} \approx \sqrt{\frac{\rho_{1}}{\rho_{2}}}$

(2) For shape: $\frac{w_{a, g, 1}}{w_{a, g, 2}} \approx \sqrt{\frac{C_{D, 2}}{C_{D, 1}}}$

(3) For size (dependent on the shape): $\frac{w_{a, g, 1}}{w_{a, g, 2}} \approx \sqrt{\frac{\mathrm{m}_{1} A_{2}}{\mathrm{~m}_{2} A_{1}}} \approx$ $\sqrt{\frac{V_{1} A_{2}}{V_{2} A_{1}}} \approx{\sqrt{\frac{d_{1}}{d_{2}}}}^{*}$

*(for spherical particles)

The experimental results clearly indicated that the physical properties of the feed material grains significantly affected the separation. To increase the efficiency of the coal beneficiation process, which in principle is based on the classification of the material by its density, it is essential to limit the effects of other feed properties, such as the differentiation of the grains shapes and sizes. It can be inferred, that reducing the diameter ratio between the smallest and the biggest grains in the processed grain-size class is vital for an effective aerodynamic separation of coal.

According to the densimetric analysis, the washability curves were drawn, which allowed for predicting the beneficiation results and assessing the effectiveness of the adopted separation process. The experimental results clearly indicated that the aerodynamic separation yielded results inferior to those predicted by the washability curves, with regard to the product quality. It is common for industrial beneficiation processes to be less effective than tests performed under laboratory conditions, even for wet enrichment methods. To draw the dedicated curves for a specific device, a significant number of trials must be performed. Alternatively, by using the results of the size and density distribution analysis, as well as knowledge regarding the aerodynamic separation mechanism, it may be possible to develop a mathematical model for predicting the results of beneficiation using the NPPS.

The operating parameter with the greatest impact on the quality and output yield of the products was the speed of the main fan, which was controlled by the frequency inverter.

It affected the negative pressure generated inside the separator and thus the speed of the air flow in the suction zone, which was the driving force behind the separation process. The influence of the fan speed on the separation process was examined through a series of experiments with different feed materials. The tests revealed technical capabilities of the device.

For approximately half of the processed raw materials in the grain-size class of $0-50 \mathrm{~mm}$, the separation resulted in a product with an LCV of approximately $22,500-23,700 \mathrm{~kJ} / \mathrm{kg}$. For some of the low-quality raw materials, it was impossible to obtain a product with a similar calorific value while maintaining the output yield at the minimal level of approximately $60 \%-70 \%$. Through separation, it was possible to improve the calorific value of such materials by approximately $2500-3000 \mathrm{~kJ} / \mathrm{kg}$. For example, raw material No. 2, with an LCV of $\sim 16,800 \mathrm{~kJ} / \mathrm{kg}$, was processed into fuel with an LCV of almost 20,000 kJ/kg. Such material meets the standard for fuel used in the power industry.

The results of the tests performed on the $0-50 \mathrm{~mm}$ materials indicated that the pneumatic separator can be used to process both low-calorific materials (to produce fuel for use in the power industry) and raw materials with an LCV exceeding $20,000 \mathrm{~kJ} / \mathrm{kg}$ (enriched to obtain fuel suitable for both industrial and municipal installations). The applicability for municipal installations might be limited owing to requirements concerning the maximum ash content of the fuel.

Relatively high calorific values were obtained through the processing of $20-50 \mathrm{~mm}$ feed material. However, the results were highly dependent on the feed origins. In most cases, the resulting product had an LCV in range of $24-26 \mathrm{MJ} / \mathrm{kg}$, and the output yield was maintained above $60 \%(60 \%-80 \%)$. Thus, in some cases, the process improved the LCV of the material by up to $6000 \mathrm{~kJ} / \mathrm{kg}$ compared with the raw feed material. For most of the feed 
materials, the tests performed on the $20-50 \mathrm{~mm}$ grain-size class yielded the best results; therefore, it can be inferred that the aerodynamic separation of coarse-grained materials is more efficient than in the case of fine-grained materials processing.

The tests and calculations indicated that narrowing the grain-size class of the feed material can significantly increase the efficiency of the pneumatic enrichment process. In practice, the processing of the $0-20 \mathrm{~mm}$ feed material resulted in similar- or even worse-quality products than the processing of grains in the $0-50 \mathrm{~mm}$ class. It is important to note, that the fractions obtained through the sieving process should be considered as new raw materials from the viewpoint of the beneficiation process, because these fractions have distinct size and density distributions. Sieving off the $20-50 \mathrm{~mm}$ grain-size class, which was found to be susceptible to the separation process, concurrently resulted in obtaining the less-susceptible $0-20 \mathrm{~mm}$ grain-size class, hence the inferior separation results.

Sieving off only the finest grains $(0-6 \mathrm{~mm})$ significantly enhanced the quality of the product, in agreement with the aforementioned influence of the particle size on the separation process. Processing the material in the grain-size class of 6-20 mm increased the LCV from approximately $20-21 \mathrm{MJ} / \mathrm{kg}$ to $25 \mathrm{MJ} / \mathrm{kg}$. Therefore, pneumatic separation allows production of ecological fuel in the grain-size class of $5-25 \mathrm{~mm}$ (which is currently popular), for dedicated use in domestic heating installations.

The study on the effectiveness of the coal enrichment process through pneumatic separation with use of the developed sorting device indicated that as for other beneficiation methods, the separation efficiency is highly dependent on the physical properties of the feed material. Tests revealed that various ROM coals-even coals originating from neighbouring mining plants-exhibit different susceptibility to the pneumatic separation process. The results indicate that the effect of narrowing the grain-size class also depends on the properties of the feed material (grain-size distribution, ash content in individual grains of different sizes).

Every feed material has unique physicochemical characteristic; thus, the optimal initial preparation method for each material should be considered, taking into account economic aspects and the required parameters of the products. The results indicated that, in the case of the tested feed materials, initial sieving into classes of $0-6,6-20$, and $20-50 \mathrm{~mm}$ was sufficient for improving the product quality. Further narrowing of the grain-size classes should be performed if the products requirements are not satisfied.

To estimate the capacity of the installation, the following parameters were taken into account: width of the conveyor belt, speed of the conveyor belt, feed material layer thickness, and bulk density of the feed material.
Considering the defined optimal feeding conditions, the capacity of the installation was estimated to be $4-8 \mathrm{t} / \mathrm{h}$, depending on type of material processed (grain-size class, density of particles).

According to the data provided by the manufacturer of the device subassemblies, the power consumption of the installation was estimated to be $16-24 \mathrm{~kW}$. Therefore, the energy consumption during operation should be in the range of $2-6 \mathrm{~kW} \mathrm{~h}$ per ton of feed material processed.

\section{Conclusions}

The performed study showed a strong possibility of application of the developed NPPS for hard coal beneficiation. The LCV of processed raw coal samples was increased by $5 \%-40 \%$ while the output yield was maintained above $60 \%$. The final result of the separation was highly dependent on the properties of the feed material. The experimental results indicated that in coal processing, the NPPS allows flexible regulation of the physical parameters of the final product. As the output yield of the sucked fraction increases, the ash contents in both the sucked and non-sucked fractions increase. A trade-off between the quality of the products and their yield must be made.

One major limitation of the process is the relatively high calorific value of the obtained waste products-this nonsucked fraction would probably have to be subjected to other processes for reducing its calorific value or used as a component for fuel blending.

In coal material processing, pneumatic separation can be used for not only raw-coal beneficiation but also coal recovery from materials stored at coal-waste dumps.

The experiments revealed that the NPPS could be used to increase the content of coal in waste materials used as the feed. For the tested materials, the separation process significantly increased the coal concentration in the product, compared with the feed material.

Such a product does not satisfy the standards for fuel but can be used as the feed for further enrichment processes using more precise methods.

The developed NPPS complements the wide arsenal of devices used in the hard-coal enrichment industry. The main advantages of the device are its mobility, low cost of material processing, and lack of water consumption during operation.

Acknowledgements The authors are thankful to the other Project partners: Elmech Kazeten Ltd., Air Separation Machinery Ltd., Tercharpol Ltd., Haldex S.A., and Bay Zoltán Nonprofit Ltd. for Applied Research for cooperation. 
Funding The research presented in this paper was performed as a part of the Project AMSEP "Novel dry sorter for coal processing and coal recovery from mine originating wastes", which was conducted with a financial grant from the European Institute of Innovation and Technology in frame of InnoEnergy S.E., with Central Mining Institute as the Project coordinator. It was also financially supported by Statutory Research No. 11325018-173.

Data availability Datasets related to this article are stored in an open-source online data repository hosted at Mendeley Data, with a https://doi.org/10.17632/57f28ph87t.1 (Stańczyk et al. 2020).

\section{Compliance with ethical standards}

Conflict of interest The authors of this paper are co-authors of the patent application "Device for pneumatic sorting of grainy materials, and method of sorting" submitted by Central Mining Institute.

Ethical standards The experiments comply with the current laws of Poland.

Open Access This article is licensed under a Creative Commons Attribution 4.0 International License, which permits use, sharing, adaptation, distribution and reproduction in any medium or format, as long as you give appropriate credit to the original author(s) and the source, provide a link to the Creative Commons licence, and indicate if changes were made. The images or other third party material in this article are included in the article's Creative Commons licence, unless indicated otherwise in a credit line to the material. If material is not included in the article's Creative Commons licence and your intended use is not permitted by statutory regulation or exceeds the permitted use, you will need to obtain permission directly from the copyright holder. To view a copy of this licence, visit http://creativecommons. org/licenses/by/4.0/.

\section{References}

Baic I, Blaschke W, Szafarczyk J (2014) Dry coal cleaning technology. J Pol Min Eng Soc 34:257-262

Baic I, Blaschke W, Sobko W, Szafarczyk J (2016) Wdrożenie innowacyjnej technologii oczyszczania węgla kamiennego przy pomocy suchej metody wzbogacania (FGX) drogą obniżenia kosztów wytwarzania produktów handlowych w krajowym górnictwie. Czasopismo Techniczne KTT nr 166

Battioui M, Mostapha B, Hassan B, Abdelhakim J (2013) Impact of mining wastes on groundwater quality in the province Jerada (eastern Morocco). Int J Eng Sci Technol 5:1601-1615

Blaschke W (2009) Przeróbka węgla kamiennego-wzbogacanie grawitacyjne (Hard coal preparation-gravitational beneficiation). Instytut Gospodarki Surowcami Mineralnymi i Energią PAN

Całus Moszko J, Iwaszenko S, Bajerski A, Janoszek T (2016) Novel dry sorter for coal processing and coal recovery from mine originating wastes. In: Litvinenko V (eds) XVIII international coal preparation congress. Springer, Cham. https://doi.org/10. 1007/978-3-319-40943-6_180

Cengel YA, Cimbala JM (2018) Fluid mechanics-fundamentals and applications, 4th edn. McGraw-Hill Education, London

Chalavadi G, Das A (2015) Study of the mechanism of fine coal beneficiation in air table. Fuel 154:207-216. https://doi.org/10. 1016/j.fuel.2015.03.063

Ciesielczuk J (2015) Chapter 16-Coal mining and combustion in the coal waste dumps of Poland. In: Sokol GBSPV (ed) Coal and peat fires: a global perspective. Elsevier, London, pp 463-473
Das A, Sarkar B, Mehrotra SP (2009) Prediction of separation performance of Floatex Density Separator for processing of fine coal particles. Int J Min Process 91(1-2):41-49. https://doi.org/ 10.1016/j.minpro.2008.11.004

Davaasuren J, Kim B-G, Lee J-H, Davaatseren G, Bazarragchaa M (2016) Dry coal preparation of fine particles by kat process. In: Litvinenko V (eds) XVIII international coal preparation congress. Springer, Cham. https://doi.org/10.1007/978-3-31940943-6_184

Dwari RK, Hanumantha RK (2007) Dry beneficiation of coal-a review. Miner Process Extr Metall Rev 28:177-234. https://doi. org/10.1080/08827500601141271

Fan G, Zhang D, Wang X (2014) Reduction and utilization of coal mine waste rock in China: a case study in Tiefa coalfield. Resour Conserv Recycl 83:24-33. https://doi.org/10.1016/j.resconrec. 2013.12.001

Fu Z, Zhu J, Barghi S, Zhao Y, Luo Z, Duan Ch (2019) Dry coal beneficiation by the semi-industrial air dense medium fluidized bed with binary mixtures of magnetite and fine coal particles. Fuel 243:509-518. https://doi.org/10.1016/j.fuel.2019.01.140

Galvin KP, Pratten SJ, Nicol SK (1999) Dense medium separation using a teetered bed separator. Miner Eng 12(9):1059-1081. https://doi.org/10.1016/S0892-6875(99)00092-8

Galvin KP, Doroodchi E, Callen AM, Lambert N, Pratten SJ (2002) Pilot plant trial of the reflux classifier. Miner Eng 15(1-2):19-25. https://doi.org/10.1016/S0892-6875(01)00193-5

Gupta N (2016) Evaluation of pneumatic inclined deck separator for high-ash Indian coals. Int J Coal Sci Technol 3:198-205. https:// doi.org/10.1007/s40789-016-0125-2

Hacifazlioglu H (2012) Application of the modified water-only cyclone for cleaning fine coals in a Turkish washery, and comparison of its performance results with those of spiral and flotation. Fuel Process Technol 102:11-17. https://doi.org/10. 1016/j.fuproc.2012.04.011

Honaker RQ, Jain M, Parekh BK, Saracoglu M (2007) Ultrafine coal cleaning using spiral concentrators. Miner Eng 20(14):1315-1319. https://doi.org/10.1016/j.mineng.2007.08. 006

Honaker RQ, Saracoglu M, Thompson E, Bratton R, Luttrell GH, Richardson V (2008) Upgrading coal using a pneumatic densitybased separator. Int J Coal Prep Util 28(1):51-67. https://doi.org/ 10.1080/19392690801934054

Honaker RQ, Luttrell G, Mohanty M (2010) Coal preparation research in the USA. In: Proceedings of XVI international coal preparation congress, Lexington, pp 864-874

Infomine Research Group (2015) Review of modern coal preparation technologies in the world

Internet Source: Wikipedia. https://en.wikipedia.org/wiki/Z-test. Retrieved 10 Apr 2020

Iskhakhov KhA, Schastlivtsev EL, Kondratenko TuA (2008) Dry enrichment of coal. Coke Chem 51:431-433. https://doi.org/10. 3103/S1068364X08110021

Joint Committee for Guides in Metrology (2008) Evaluation of measurement data-guide to the expression of uncertainty in measurement

Klonecki W (1999) Statystyka dla inżynierów (Statistics for Engineers). Wydawnictwo Naukowe PWN

Lockhart NC (1984) Dry beneficiation of coal. Powder Technol 40:17-42. https://doi.org/10.1016/0032-5910(84)85053-6

Mijał W, Tora B (2018) Development of dry coal gravity separation techniques. IOP Conf Ser Mater Sci Eng 427(1):012003

NASA Glenn Research Center (2015) The drag equation. https:// www.grc.nasa.gov/WWW/K-12/airplane/drageq.html. Retrieved 13 Apr 2020 
NASA Glenn Research Center (2018) Terminal velocity. https:// www.grc.nasa.gov/WWW/K-12/airplane/termv.html. Retrieved 13 Apr 2020

Nguyentranlam G, Galvin KP (2001) Particle classification in the reflux classifier. Miner Eng 14(9):1081-1091. https://doi.org/10. 1016/S0892-6875(01)00113-3

Patil DP, Parekh BK (2011) Beneficiation of fine coal using the air table. Int J Coal Prep Util 31(3-4):203-222. https://doi.org/10. 1080/19392699.2011.574948

PN-EN 933-3 (1999) Badania geometrycznych właściwości kruszyw-Część 3: Oznaczanie kształtu ziaren za pomocą wskaźnika płaskości. (Tests for geometrical properties of aggregates-Part 3: Determination of grain shape using the flakiness index)

Sahu AK, Biswal SK, Parida A (2009) Development of air dense medium fluidized bed technology for dry beneficiation of coala review. Int J Coal Prep Util 29:216-241. https://doi.org/10. 1080/19392690903113847

Sarkar B, Das A, Mehrotra SP (2008) Study of separation features in floatex density separator for cleaning fine coal. Int $\mathrm{J}$ Miner Process 86(1-4):40-49. https://doi.org/10.1016/j.minpro.2007. 10.002

Stańczyk K, Bajerski A, Łączny MJ (2020) Negative-pressure pneumatic separator: a new solution for hard-coal beneficiation: datasets and supplementary materials. Mendeley Data. https:// doi.org/10.17632/57f28ph87t.1

US Department of Energy (2016) International energy outlook 2016. Energy Information Administration, Office of Energy Analysis. https://www.eia.gov/outlooks/archive/ieo16/
US Department of Energy (2017) International energy outlook 2017. Energy Information Administration, Office of Energy Analysis. https://www.eia.gov/outlooks/archive/ieo17/

Van Houwelingen JA, De Jong TPR (2004) Dry cleaning of coal: review, fundamentals and opportunities. Geol Belg 7:335-343

Vasumathi N, Vijaya Kumar TV, Ratchambigai S, Subba Rao S, Prabhakar S, Bhaskar Raju G (2016) Beneficiation of an Indian non-coking coal by column flotation. Int J Coal Sci Technol 3:206-214. https://doi.org/10.1007/s40789-016-0129-y

Wang N, Shen R, Wen Z, De Clercq D (2019) Life cycle energy efficiency evaluation for coal development and utilization. Energy 179:1-11. https://doi.org/10.1016/j.energy.2019.04.111

World Energy Council (2013) World energy resources: 2013 survey. https://www.worldenergy.org/publications/entry/world-energyresources-2013-survey

World Energy Council (2016) World energy resources: coal 2016

Xuliang Y, Yuemin Z, Gongmin L, Zhenfu L, Zengqiang C, Chuncheng L (2012) Establishment and evaluation of a united dry coal beneficiation system. Int J Coal Prep Util 32(2):95-102. https://doi.org/10.1080/19392699.2011.640299

Yang Y, Ge L, He Y, Xie W, Ge Z (2019) Mechanism and fine coal beneficiation of a pulsating airflow classifier. Int J Coal Prep Util 39(1):20-32. https://doi.org/10.1080/19392699.2017.1288622

Zhao Y, Yang X, Luo Z, Duan Ch, Song S (2014) Progress in developments of dry coal beneficiation. Int J Coal Sci Technol 1:103-112. https://doi.org/10.1007/s40789-014-0014-5 